\title{
Substrates specialization in lipid compounds and hydrocarbons of Marinobacter
}

\section{genus}

Patricia Bonin ${ }^{1}$, Christophe Vieira ${ }^{1,2}$, Régis Grimaud ${ }^{3}$, Cécile Militon ${ }^{1}$, Philippe Cuny ${ }^{1}$, Oscar Lima ${ }^{1,4}$, Sophie Guasco, Corina P.D. Brussaard ${ }^{5}$, Valérie Michotey ${ }^{1 *}$,

1: Aix Marseille Université, CNRS, Université de Toulon, IRD, MIO UM 110, 13288, Marseille, France

2: present adress : Sorbonne Universités, UPMC Univ Paris 06, IFD, 4 Place Jussieu, 75252 PARIS cedex 05, France

3: Institut Pluridisciplinaire de Recherche en Environnement et Matériaux, Equipe Environnement et Microbiologie, UMR 5254, CNRS, IBEAS, Université de Pau et des Pays de l'Adour, Pau, France

4 : present adress Ecosystèmes, biodiversité, évolution (ECOBIO), CNRS : UMR6553 - Université de Rennes 1 - INEE - Observatoire des Sciences de l'Univers de Rennes, France

5: Royal Netherlands Institute for Sea Research, Department of Biological Oceanography NL-1790 AB Den Burg, Netherlands

*Corresponding author: Valerie michotey, valerie.michotey@univ-amu.fr

Address: Campus de Luminy, case 901, av de Luminy, 13288 Marseille Cedex , France, (33(0)491829623)

Keywords: Marinobater, Hydrocarbon, marine sediment, quantification, electron donor pattern, denitrification

\begin{abstract}
The impact of petroleum contamination and of burrowing macrofauna on abundances of Marinobacter and denitrifiers was tested in marine sediment mesocoms after 3 months incubation. Quantification of this genus by qPCR with a new primer set showed that the main factor favoring Marinobacter abundance was hydrocarbon amendment followed by macrofauna presence. In parallel, proportion of nosZ-harbouring bacteria increased in the presence of marcrofauna. Quantitative finding were explained by physiological data from a set of 34 strains and by genomic analysis of 16 genomes spanning 15 different Marinobacter validated species (M. hydrocarbonoclasticus, M.daeopensis, M. santoriniensis, M. pelagius, M. flavimaris, M. adhaerens, M. xestospongiae, M. algicola, M. vinifirmus; $M$. maritimus, $M$. psychrophilus, M. lipoliticus, M. manganoxydans, , M. excellens, M. nanhaiticus) and 4 potential novel ones. Among the 105 organic electron donors tested in physiological analysis, Marinobacter pattern appeared narrow for almost all kinds of organic compounds except lipid ones. Strains of this set could oxidize a very large spectrum of lipids belonging to glycerolipids, branched-, fatty acyls-, and aromatic hydrocarbon classes. Physiological data were comforted by genomic analysis and genes of alkane 1-monooxygenase, haloalkane dehalogenase and flavin-binding monooxygenase were detected in most genomes. Denitrification was assessed for several strains belonging to $M$. hydrocarbonoclasticus, $M$. vinifirmus, M. maritinus, M. pelagius species indicating the possibility to use nitrate as alternative electron acceptor. Higher occurrence of Marinobacter in presence of petroleum appeared to be the result of a broader physiological trait allowing this genus to use lipids including hydrocarbon as principal electron donors.
\end{abstract}




\section{Introduction}

The Marinobacter genus was first described in 1992 (Gauthier et al. 1992) and belongs to the $\gamma$ Proteobacteria class and the Alteromonadaceae family. They are Gram negative and mostly facultative aerobic heterotrophic bacteria. The genus includes 30 Marinobacter species currently validated. Some of them can grow anaerobically by nitrate reduction $(20 / 30)$ and some of them $(6 / 30)$ have been further characterized as denitrifiers (able to perform reduction of nitrate to $\mathrm{N}_{2}$ by respiratory process) (Handley and Lloyd 2013)

Presently, more than 3871 sequences of 16S rRNA genes affiliated to the genus Marinobacter are available in the RDP ribosomal database from either isolates or clone strains. Heighten genomes are deposited in different banks. Bacteria belonging to genus Marinobacter are commonly detected in diverse marine environments such as coastal marine sediments (Gauthier et al. 1992; Gorshkova et al. 2003), waters (Yoon et al. 2004), and sea sand environments (Kim et al. 2006), deep-water sediments (Cui et al. 2008; Edwards et al. 2003) hydrothermal vents (Shieh et al. 2003), mud volcanoes (Yakimov et al. 2002), hypersaline microbial mats (Abed et al. 2007; Bordenave et al. 2007), sediments of mangrove (Brito et al. 2006), alkaline seabed (Takai et al. 2005), sea ice of the Arctic (Deppe et al. 2005) or the Antarctica (Bowman et al. 1997; Mikucki and Priscu 2007), sediments of the deep Arctic waters (Martin et al. 2003). Representatives of this genus have also been identified associated with the bacterial flora of marine organisms. Indeed, they were isolated from photosynthetic unicellular organisms such as dinoflagellates secreting paralyzing toxins (Gymnodinium catenatum and Alexandrium tamarense) (Green et al. 2006) as well as multicellular organisms such as bryozoans (Romanenko et al. 2005) and sponges (Lee et al. 2012). Thus Marinobacter seems to colonize a wide variety of marine ecosystems around the world ranging from psychrophilic to thermophilic environments with a high tolerance to salinity and $\mathrm{pH}$. Their ability to occupy diverse physicochemical regimes seems an indication of large phenotypic versatility.

Recently metagenomic analyses have highlighted the presence of Marinobacter sequences at relatively high percentage in oil polluted environments. Ribosomal or denitrifying genes affiliated to the genus Marinobacter have been identified in oil spill simulation mesocosms with marine coastal sediment (Stauffert et al. 2014), estuarine sediment (Gray et al. 2011) or mangrove sediment (dos Santos et al. 2011). Metatranscriptomic analysis revealed that strains belonging to Marinobacter genus are active in polluted environments. In a study on the Deep Horizon spill, Marinobacter aquaolei strain VT8 genome (now affiliated with $M$ hydrocrabonoclasticus) was the closest match to metatranscriptomes (Lamendella et al. 2014). Moreover, in anoxic mesocosm, Marinobacter strain alkB cDNA, coding for a hydroxylase involved in degradation of short-chain alkanes, has been quantitatively detected by qPCR (Genovese et al. 2014). These results led some authors to propose the use of sequences of the genus Marinobacter as one of the proxies for oil pollution monitoring (dos Santos et al. 2011; Genovese et al. 2014; Gray et al. 2011). Molecular approaches alone are 
however, unable to establish a relationship between the presence of a genus and its real ecophysiological role in the studied ecosystem. In order to tackle this drawback, it is necessary to complement molecular information with physiological data on hydrocarbon degradation capacities of strains belonging to different Marinobacter species. Although the properties towards hydrocarbon degradation of some type strains have been investigated (for a review see (Duran 2010), it should extend to more strains and to several isolates of the same species. In a broader approach, the determination of the ecological role of Marinobacter needs further investigation on their electron donor pattern.

With the exception of the most superficial layer, bulk of marine sediments are assumed to be anoxic (Canfield et al. 1993) especially when contaminated with hydrocarbons due to the reduction of oxygen diffusion. The ability to use alternative electron acceptors is then an ecological advantage for bacterial communities. The capability to perform nitrate reduction in anaerobiosis has been frequently reported for Marinobacter and denitrification for at least some strains. This feature need also to be further explored.

This study intends to analyze the robustness of Marinobacter proxy as hydrocarbon pollution applying genus dynamic in the face of oil contamination, physiological analysis toward hydrophobic and hydrocarbons compounds and anaerobic respiration. Their dynamic upon contamination with petroleum has been investigated by qPCR with new primer set, in marine sediment mesocosms. Due to the impact of burrowing macrofauna on oxygen supply and on in situ nitrate production resulting of the activity of nitrifying prokaryotes, this condition has been also tested. In parallel investigations on the physiological characteristics of Marinobacter has been undertaken with 34 isolates pertaining to 7 validated species and 3 potential novel ones in order to determine their spectrum of electron donors and their potentiality regarding denitrification. The analysis of 16 genomes has permitted to enlarge these observations to 8 additional validated species and to one potential novel one.

\section{Materials and Methods}

Bacterial strains and isolation procedures: The bacterial strains studied belong to the genus Marinobacter. The set of strain comprised collection strains (M. hydrocarbonuclasticus, M. aquaolei, M.algicola) and strains isolated from previous studies from Mediterranean sediments (Bonin et al. 1987; 1992; Goregues et al. 2004; Rontani et al. 1997) (Fig. 1).

Other strains $(23 \mathrm{w} 2 \mathrm{~b}, 23 \mathrm{tet} 5 \mathrm{~b}$, cubw5a, cubw5b, cubtrip $2 \mathrm{~b}$ and cubtet $1 \mathrm{~b})$ have been isolated in the frame of this study from North Sea water (Fig. 1). Samples were collected on board the RV Pelagia during May 2008. Strains $23 \mathrm{w} 2 \mathrm{~b}, 23$ tet $5 \mathrm{~b}$ were isolated from samples of surface water contaminated by an oil slick collected at $53^{\circ} 45^{\prime} 50.4^{\prime \prime N} 4^{\circ} 11^{\prime} 15.7914 " E$. Strains, cubw5a, cubw5b, cubtrip2b and cubtet1b were isolated from samples retrieved from a $1 \mathrm{~m}^{3}$ on-board mesocosm filled with seawater collected at $55^{\circ} 8^{\prime} 23.208^{\prime \prime} \mathrm{N} 3^{\circ} 11^{\prime}$ 
9.672" E at $29 \mathrm{~m}$ deep and contaminated with crude oil. Mesocosm were incubated seven days at ambient temperature on the deck before sampling for strain isolation. Seawater samples, either from sea or mesocosms were used to inoculate enrichment cultures in ASW (Baumann and Baumann 1981) containing tetradecane, paraffin or tripalmitate as sole carbon source. Colonies isolation was performed on agar ASW plates with acetate lactate glucose and yeast extract as carbon sources.

Electron donors screening: Electron donors were tested with Biolog GN microplates (Biolog TNC, Hayward, CA,USA). Cells were grown in ASW containing ammonium $(1 \mathrm{~g} / \mathrm{L})$ and a mixture of different carbon sources (lactate $1 \mathrm{~g} / \mathrm{L}$, acetate $1 \mathrm{~g} / \mathrm{L}$, glucose $1 \mathrm{~g} / \mathrm{L}$, yeast extract $2 \mathrm{~g} / \mathrm{L}$, peptone $2 \mathrm{~g} / \mathrm{L}$ ). Cultures in exponential phase of growth were pelleted, washed once in ASW without carbon source. Biolog GN microplates were inoculated with the cell suspensions as described in the manufacturer instructions. Utilization of carbon sources was detected as an increase in the respiration rate of cells in the well of a microplate, leading to irreversible reduction of the tetrazolium dye INT [2-(p-iodopheny)-3-(p-nitropheny)-5-phenyl tetrazolium chloride]. A positive utilization reaction was indicated when a purple color formed due to INT-formazan formation in a well after one week incubation at $20^{\circ} \mathrm{C}$. Biolog GN microplates contained the following carbon sources that could be used as electron donor in aerobiosis: 30 carbohydrates ( $\alpha$-Cyclodextrin, Dextrin, Glycogen, N-Acetyl-D-Galactosamine, N-Acetyl-D-Glucosamine, Adonitol, L-Arabinose, D-Arabitol, DCellobiose, i-Erythritol, D-Fructose, D-Fucose, D-Galactose, Gentiobiose, $\alpha$-D-Glucose, $\alpha$-D-Lactose, Lactulose, Maltose, D-Mannitol, D-Mannose, D-Melibiose, $\beta$-Methyl-D-Glucoside, D-Psicose, D-Raffinose, L-Rhamnose, D-Sorbitol, Sucrose, D-Trehalose, Turanose, Xylitol), 19 amino-acids (D-Alanine, L-Alanine, L-Alanyl-Glycine, L-Asparagine, L-Aspartic Acid, L-Glutamic Acid, Glycyl-L-Aspartic Acid, Glycyl-LGlutamic Acid, L-Histidine, Hydroxy-L-Proline, L-Leucine, L-Ornithine, L-Phenylalanine, L-Proline, DSerine, L-Serine, L-Threonine, D,L-Carnitine, $\gamma$-Aminobutyric Acid), 30 organic acids (Pyruvic Acid Methyl Ester, Succinic Acid Mono-Methyl Ester, Acetic Acid, Cis-Aconitic Acid, Citric Acid, Formic Acid, DGalactonic Acid Lactone, D-Galacturonic Acid, D-Gluconic Acid, D-Glucosaminic Acid, D-Glucuronic Acid, $\alpha$-Hydroxybutyric Acid, $\beta$-Hydroxybutyric Acid, $\gamma$-Hydroxybutyric Acid, p-Hydroxy-phenylacetic Acid, Itaconic Acid, $\alpha$-Ketobutyric, $\alpha$-Ketoglutaric Acid, $\alpha$-Ketovaleric Acid, D,L-Lactic Acid, Malonic Acid, Propionic Acid, Quinic Acid, D-Saccharic Acid, Sebacic Acid, Succinic Acid, Bromosuccinic Acid, Succinamic Acid, L-Pyroglutamic Acid, Urocanic Acid), 3 alcools (m-Inositol, 2,3-Butanediol, Glycerol) et 13 other substrates (tween 40, tween 80, Glucuronamide, L-Alaninamide, Inosine, Uridine, Thymidine, Phenylethyl-amine, Putrescine, 2-Aminoethanol, D,L, $\alpha$-Glycerol Phosphate, $\alpha$-D-Glucose 1-Phosphate, DGlucose-6-Phosphate) .

For insoluble substrates, strains were inoculated on ASW agar plates containing ammonium $(1 \mathrm{~g} / \mathrm{L})$ and one of the following electron donors : Aromatic Hydrocarbon: fluoranthene $(1 \mathrm{mg} / \mathrm{mL})$, phenantrene $(1 \mathrm{mg} / \mathrm{mL})$, dodecylbenzene $(1 \mu \mathrm{L} / \mathrm{mL})$; Fatty acyl hydrocarbon: tetradecane $(1 \mu \mathrm{L} / \mathrm{mL})$, heptadecane $(1 \mu \mathrm{L} / \mathrm{mL})$, wax 
ester ( hexadecyl d'hexadecanoate ; $0.625 \mathrm{mg} / \mathrm{mL}$ ), paraffin (mixture of C19 to C31 alkanes with melting point $\left.52^{\circ} \mathrm{C} ; 2.5 \mathrm{mg} / \mathrm{mL}\right)$; Branched hydrocarbon: pristane $(1 \mu \mathrm{L} / \mathrm{mL})$, glycerolipids: triolein $(5 \mu \mathrm{L} / \mathrm{mL})$, tripalmitin $(7.5 \mathrm{mg} / \mathrm{mL})$. Plates with a mixture of soluble carbon sources or no carbon source were also used as positive and negative control respectively. The plates were incubated aerobically at $20^{\circ} \mathrm{C}$ for two weeks and then overlaid with $10 \mathrm{~mL}$ molten soft agar containing INT $(0.2 \mathrm{~g}$ per liter ASW) and the same carbon source than that used for the growth step. Oxygen respiring colonies in the presence of the selected substrates were identified as those reducing colorless INT into red INT-formazan (Goregues et al. 2004). Results were recorded after 30 minutes incubation.

Mesocosm set up: Sediment was collected at Brittany coast (Celtic Sea, Atlantic Ocean, $48^{\circ} 34^{\prime} 28.2^{\prime}{ }^{\prime} \mathrm{N} 4^{\circ}$ 36'40.2" E) in October 2013. After removing macrofauna, $72 \mathrm{~L}$ of sediments were distributed in 12 mesocosms (boxes 15x20x $30 \mathrm{~cm}$ ). Four conditions were established in triplicate (1) No Nereis ( Hediste. diversicolor) addition and no hydrocarbon amendment (-HC-N), (2) Nereis addition at density of 1000 organism $/ \mathrm{m}^{2}$ and no hydrocarbon amendment $(-\mathrm{HC}+\mathrm{N})(3)$ no Nereis addition and hydrocarbon amendment at $7 \mathrm{~g} / \mathrm{kg}(+\mathrm{HC}-\mathrm{N})$, (4) Nereis addition at density of 1000 organism $/ \mathrm{m}^{2}$ and hydrocarbon amendment at $7 \mathrm{~g} / \mathrm{kg}$ $(+\mathrm{HC}+\mathrm{N})$,. Hydrocarbon addition consist in Ural type petroleum topped at $100^{\circ} \mathrm{C}$ (removal of $\mathrm{HC}<7 \mathrm{C}$ ).

\section{Nucleic acid extraction, quantification by qPCR in mesocoms and characterization of genes of denitrification on strains set}

After 3 months of incubation at $20^{\circ} \mathrm{C}, 5 \mathrm{~g}$ of the 2 first centimeters of sediment in each mesocosm were sampled and nucleic acids were extracted using the MoBio Power soil RNA/DNA extraction kit (MoBio Laboratories, California) according to the manufacturer's protocol. DNAs from cultures of strains were purified as previously reported (Goregues et al. 2005). Purified DNA was stored at $20^{\circ} \mathrm{C}$ until use.

The determinations of 16S rRNA gene copy numbers were performed by real time PCR with SsoAdvanced SYBR Green Supermix using a CFX96 Real Time System (C1000 Thermal Cycler, Bio-Rad Laboratories, CA, USA). The primer sets GML5F-Uni516R (Michotey et al. 2012) and marinob300F (5'GACTGAGACACGGCCCGA-3') - marinob600R (5'-CCGGGGCTTTCACATCTCG-3') were used for quantification of total bacterial 16S rRNA genes and Marinobacter 16S rRNA genes respectively. The real time PCR cycles consisted of a denaturation step of $5 \mathrm{~s}$, a hybridization step of $20 \mathrm{~s}$ at $56^{\circ} \mathrm{C}$ with an elongation step of $40 \mathrm{~s}$. Quantification of bacterial nosZ were performed using nosZ $1211 \mathrm{~F}$ and nosZ 1897R primers (Rosch et al. 2002) and SsoFast EVA Green Supermix (Bio-Rad Laboratories, CA, USA). The real time PCR cycles consist of a denaturation step of $15 \mathrm{~s}$, a hybridization step of $15 \mathrm{~s}$ at $64^{\circ} \mathrm{c}$ with an elongation step of $40 \mathrm{~s}$ at $72^{\circ} \mathrm{C}$. Gene abundance in microcosm DNA samples was determined in relation with a calibration standards corresponding to dilution of plasmids harboring target genes. 
Denitrification activity of strains were determined as previously described (Bonin et al. 1987; 1992; Goregues et al. 2004; Rontani et al. 1997). The detection by PCR on genome of the strains of of narG, nirS and nosZ were performed as previously reported(Goregues et al. 2005, Michotey et al. 2000, Rosch et al. 2002) respectively. All amplified DNA fragments were checked by sequencing. The nucleotide sequence data generated in this study have been deposited in the Genbank database under accession numbers KM816585 to KM816618.

Genomes analysis: Sixteen genomes are currently available, M. adhaerens DSM 23420 (CP001978), M. algicola DG893(GCA_000170835.1), $M$ hydrocarbonoclasticus strain VT8 (GCA_000015365.1), M. hydrocarbonoclasticus strain 17 ATCC 49840 (FO203363 ), M excellens (PRJNA195885 ), M. daepoensis DSM 16072 (GCA_000421165.1), M. lipolyticus strain BF04 (GCA_000372805.1), M. lipoliticus strain SM19 (ASAD01000001- ASAD01000006), M. maganoxydans (AGTR00000000), M. nanhaiticus (APLQ01000000) M. santoriniensis (APAT01000000), M. strain AK21 (ANIE01000001- ANIE01000006), M. strain BSs20148 (CP003735 ), M. strain ELB17 (GCA_000169375.1), M. strain MCTG268 (JQMK00000000), M. strain HL-58 (GCA_000686085.1). The metabolic properties harbored by the strain according to their genomes analyses was assessed with IMG-ER (DOE-JGI) platform (https://img.jgi.doe.gov)

Statistical analysis: An ANOVA analysis was used to determine the influence of hydrocarbon amendment and presence of Nereis on bacterial numeration in microcosms. The significance level for all tests was set at $\mathrm{p}<0.05$. All tests were performed with XLSTAT ${ }^{\circledR}$ (XLSTAT software ${ }^{\circledR} 2008$, Addinsoft, Paris).

\section{Results}

In this study we propose new qPCR primers for the detection of Marinobacter ribosomal 16S rDNA (Table 2). Primer set Marinob300f-Marinob600R matches with 64.5\% of ribosomal sequences affiliated to Marinobacter genus in RDP database and $90 \%$ of ribosomal sequence of Marinobacter type strains. Previous qPCR primers (Mab451f-Mab573r) and CARD-FISH probe presented a narrower spectrum of detection since they matched with 6.4 and $26.6 \%$ of Marinobacter ribosomal sequences in RDP, respectively. These percentages dropped to 3 and 20\% for type strains. (Tab.2). Both qPCR primer sets present lower percentage of match toward nontarget sequences $(1.2 \%$ and $2.8 \%)$ in comparison of CARD-FISH probes $(20 \%)$. Optimization of hybridization temperature of the $\mathrm{qPCR}$ was determined $\left(\mathrm{T}=56^{\circ} \mathrm{C}\right)$ in relation with positive (M. hydrocarbonoclasticus) and negative (E. coli) Gammaproteobacteria controls. The resulting conditions lead to a qPCR efficiency of $97.1 \%$ $\left(\mathrm{R}^{2}=0.994\right)$.

Marinobacter dynamic was monitored upon hydrocarbon pollution in sediment mesocosms. Marinobacter and bacterial 16S rRNA gene abundances were measured by qPCR in all mesocosms after 3 months incubations 
(Fig. 1). The highest number of bacterial ribosomal genes (about $10^{11} / \mathrm{g}$ sediment) was observed for the condition without macrofauna and hydrocarbon. For the other conditions, no significant difference in numeration of bacterial 16S rRNA genes was recorded in the mesocosms (about $10^{10} / \mathrm{g}$ sediment) (Fig. 1). The analysis of abundance of Marinobacter ribosomal genes emphasized the predominant impact of hydrocarbon to presence of macrofauna. Indeed, all mesocosms containing hydrocarbon presented significant higher numbers of Marinobacter $(+\mathrm{HC}+\mathrm{N},+\mathrm{HC}-\mathrm{N}>-\mathrm{HC}+\mathrm{N},-\mathrm{HC}-\mathrm{N} ; \mathrm{p}<0.05)$. Their abundance reached $0.3-$ $0.09 \%$ of the bacterial population in presence of $\mathrm{HC}$ in comparison of $0.02-0.004 \%$ in its absence. Whatever the presence of hydrocarbon, the mesocosms without macrofauna harbored lower percentage of Marinobacter than those in which Nereis has been introduced ( 0.3 vs 0.09 and 0.022 vs 0.004 for condition with and without hydrocarbons).

The denitrifying community was quantified using nos $Z$ gene with primers previously used for competitive PCR (Rontani et al. 2010, Fernandes et al. 2012). In qPCR the efficiency of the reaction reached 91.7\%. In mesocosms, the number of bacterial nos $Z$ varied form $6.6610^{6}$ to $3.2410^{7} / \mathrm{g}$ sediment (Fig.1). The ratio nosZ/16S rRNA bacterial genes ranged from $0.1410^{-3}$ to $0.0710^{-3}$ in mesocosms without hydrocarbon amendment to $1.4710^{-3}$ to $0.5710^{-3}$ in its presence. Within a condition ( + or - hydrocarbon) this ratio was higher in presence of macrofauna. In contrast, the ratio denitrifier /Marinobacter (nosZ/Marinobacter 16S rRNA gene)n seemed relatively stable and range between 0.48 and 1.72 (Fig. 1).

The electron donor pattern was determined on a set of 34 isolates which according to phylogenetic tree belong to 7 validated species and 3 potential novel ones referred as phylotype \# 2, \#8, \#9 (S1). Hereafter, validated species and potential novel ones were referred as taxa. Of the 34 tested strains, only 8 were able to use a few carbohydrates as electron donors (S2). All the strains were only able to use less than 4 different carbohydrates, excepted strain T33 (phylotype \#8) oxidizing 16 of them. Glucose was the most commonly utilized (6 isolates) but only occasionally within a taxon (1/11 for $M$ hydrocarbonoclasticus, 2/8 for $M$. vinifirmus; $1 / 2$ for $M$ maritimus, 2/4 for phylotype \#8). The same trend was observed for dextrin since only 4 strains were able to use it (S2). Likewise, amino acid utilization range of Marinobacter strains of this study was restricted to few them; however in contrast to carbohydrates, most of the strains of a taxon shared the same trend toward a given Amino acid. L-proline was the most frequently used by the isolates (8/10 taxa) followed by L-glutamic acid (5/10 taxa) and then L-leucine, (4/10 taxa) (Fig.2). L alanine and D-alanine were oxidized by only few strains within 3 and 4 taxa respectively (S2). Eight out of 30 organic acids tested could be used as electron donors by a least one Marinobacter strain. The most widely used acid was $\beta$-hydroxybutyric acid that was electron donor for 8/10 taxa followed by pyruvic acid methyl ester or D,L lactic acid that were oxidized by 4/10 taxa (Fig.2). The utilization of these 3 organic acids was shared by most of the strains in a taxon (Fig.2 
and S2). In contrast, propionic acid, acetic acid, citric acid, succinic acid and bromo-succinic acid were oxidized at a lesser extent and only occasionally within a taxon.

Among the investigated panel of electron donors, the most used were lipid compounds. All tested molecules were used by several taxa of Marinobacter and all taxa, excepted M. xestospongia strain BP42, could utilized more than half of them. M. hydrocarbonoclasticus and $M$. vinifirmus, represented by 11 and 8 isolates respectively, were used to analyze the representativeness of trait within a taxon. Tween 40 (Polyoxyethylene (20) sorbitan monopalmitate) and Tween 80 (Polyoxyethylene (20) sorbitan monooleate) that are emulsifiers, or triolein that is a glycerolipid were oxidized by all taxa. This feature is also observed for heptadecane, a C17- alkane belonging to fatty acyls. These latter patterns were shared by more than $75 \%$ of the isolates of a taxon in most all cases. The two other alkanes tested, tetradecane, a linear -C14 and pristane, a branched C19 molecule, were oxidized by $9 / 10$ and $6 / 10$ taxa, respectively. Pristane utilization is sparse since only $9 \%$ of isolates of M. hydrocarbonoclasticus ( $9 \%$ ) and $25 \%$ of M. vinifirmus (25\%) were positive, suggesting that it cannot be considered as specific trait of a species. The other substrate molecules were characterized by their low lability due to the presence of one or more aromatic cycles or due to higher melting point. The 3 aromatic molecules, dodecylbenzene, phenanthrene or fluorenthene were oxidized by $6 / 10,5 / 10$ and $6 / 10$ taxa respectively. As for pristane, the utilization pattern of aromatic hydrocarbon was not identical for most of the strain within a taxon. For example, only $18 \%$ and $64 \%$ of $M$. hydrocarbonoclasticus and $12 \%$ and $25 \%$ of $M$. vinifirmus could use fluorenthene or dodecylbenzene respectively. This trend was also observed for very insoluble substrates pertaining to fatty acyls or glycerolipids such as tripalmitate paraffin and wax. Between 5 and 7 taxa were positive for their utilization, with positive strains varying between 12 to $55 \%$ for $M$. hydrocarbonoclasticus and M. vinifirmus.

The available genomes corresponded to 10 validated species ( $M$. adhaerens, M. algicola, $M$ hydrocarbonoclasticus, $M$ excellens, M. daepoensis, M. lipolyticus, M. maganoxydans, M. nanhaiticus, M. santoriniensis, M. psychrophilus ) and a potential novel one (M. sp AK21) (S1). From the analysis of available genomes, similar trends could be emitted on nature of electron donor of Marinobacter. The genomic analysis was focused on proteins mediating the entry of substrates into the cell (translocation protein, transporter, permease, symport) or the first enzyme of a pathway for lipids (Tab. 3). To import many carbohydrates (glucose, mannose, fructose...), Bacteria have developed an unique mechanism the phosphoenolpyruvate:sugar phosphotransferase system (PTS). This system synchronizes the transport of the sugar through the cellular membrane and its phosphorylation. With some variations, the PTS comprises several proteins, some of them are common for all sugars such as EnzI and HPr and others that are specific of a carbohydrate or a group or carbohydrates such as EnzII composed of domain IIA, IIB, IIC. This latter one is located in the membrane and mediates specific sugar translocation. Whereas HPR has been identified in all genomes of Marinobacter, EnZII were scarce (Tab.3). From the panel of genomes, only EnZII A and B genes specific to fructose have been identified in 8 and 5 genomes, respectively; in contrast to EnZII $\mathrm{C}$ for which 
whatever the sugar, no gene could be identified. The absence of the protein responsible for of sugars translocation led to the impossibility to use these compounds as electron donors. For some organic acids such lactate or succinate, putative genes annotated as transporters were found in 5 and 16 genomes, respectively. Proline appeared as an important amino acid since all genomes harbored a sodium/proline symporter. Except the Carboxylate/Amino Acid/Amine transporter that was present on all genomes, the other specific amino acid transporters were either absent or present in only one genome. In contrast, all the strains contained the fatty oxidation complexes $F a d A B$ and a complete $\beta$-oxidation pathway (data not shown). Furthermore, the occurrence of both alkane mono-oxygenase (alkA) and haloalkane dehalogenase genes in genomes was above $87 \%$. The only genome in which alkA has not been detected is M. lipoliticus strain BF04. The genome of this strain did not contain also the gene coding for haloalkane dehalogenase as that of M psychrophylus BSs20148. Long chain alkanes $\left(\mathrm{C}_{32}\right.$ and longer) are oxidized by the product of gene alm $A$ that encodes a flavin-binding monooxygenase. Blast search with almaA sequence of M. lipolyticus (FJ263110) from the study of Wang and Shao (2012) and with an E-value cutoff at $10^{-5}$, permit the identification of 13 homologous genes in Marinobacter set of genome. The two strains of $M$. hydrocarbonoclasticus, all 3 strains of $M$ algicola, and strains of $M$ adhaerens, M. manganoxydans, M. daepoensis, M. santoriniensis, M. nanhaiticus, M. excellens, M.lipolyticus SP19 and $M$ strain AK21 were positive.

During denitrification, nitrate is reduced into $\mathrm{N}_{2}$ through several steps. Nitrate can be reduced to nitrite by NarG or NapA, nitrite to nitric oxide by NirS or nirK, nitric oxide to nitrous oxide by NorB, and nitrous oxide to $\mathrm{N}_{2}$ by NosZ. Three genes out of four were tested. Analyses of denitrifying genes revealed the preferential presence of narG, nirS among our denitrifying Marinobacters set (Table 4). Most of the nitrate reducers among our set of strains were able to perform total denitrification and harbored also nosZ. This tendency was also found by genomic approach (Table 3). Denitrification genes the most frequently recovered were $n a r G$ and nos $Z$ and $75 \%$ of the genomes possessed at least one gene of denitrification.

\section{Discussion}

Hydrocarbons occur as biosynthetic products of living organisms in the biosphere (Ladygina et al. 2006) or as abiotic transformation products of biogenic organic matter in the geosphere (Seewald 2003). They are the main constituents of petroleum and thus are extremely abundant in geological systems. They can be transferred from geosphere to biosphere by different manners such as hydrothermal vent, mud volcano (Whiticar and Suess, 1990; Timmis 2010) or drilling problems. In consequence their presence is probably ubiquitous but in various proportions. Marine ecosystems are frequently exposed to oil pollution. After a spill, the $n$-alkanes, short chains tend to evaporate or dissolve in seawater. In contrast to short and medium-chain alkanes that are quickly degraded after the spill, the long-chain molecules with more than 18 carbon atoms, do not dissolve nor degrade efficiently and stay for longer periods of time in the environment. Hydrocarbons of a 
spill or from biogenic origin enter with other compounds in the composition of marine organic matter resulting in a complex mixture of molecules having various compositions, physical structures and reactivity. This complexity is probably a major factor for maintaining a high degree of diversity among prokaryotes in oceans. Heterotrophic bacteria recycle dissolved and particulate organic matter and contribute to the productivity of the ecosystem. Isolation campaigns have demonstrated the presence of the heterotrophic Gammaproteobacteria Marinobacter in many marine environments exhibiting disparate characteristics. This finding would suggest that they are capable of oxidizing a wide range of carbon substrates. This physiological studies of 34 isolates and analyses of 16 genomes from diverse marine habitats such as sediment, water column or phycosphere and partitioning into 15 species and 4 potential novel ones within Marinobacter genus give rise to a different view. Except for some strains, very few molecules classified as labile organic matter are used. The spectra of carbohydrates utilization as electron donors determined by physiological as well as genomic approaches are extremely reduced. Comparison of physiological and genomic approaches focusing on transporters was evaluated by comparison of patterns obtained from Marinobacter hydrocarbonoclasticus strain17. From its genome fully annotated (Grimaud et al. 2012), no EnzIIC of sugar could be detected in congruence with results of physiological study. The inability to use carbohydrates or to degrade the polysaccharides has been reported previously for some Marinobacter strains (Bowman and McMeekin 2005). However, our results including a wider list of species and with several strains within a species strengthen this observation that appears as a common trait of this genus.

The ability of Marinobacter to use external amino acids as electron donors was reported. The list of the preferential ones included L-alanine, D glutamate and L phenylalanine (Handley and Lloyd 2013). From our data, the most frequently used by our set of strains is proline and all analyzed genomes contained a specific transporter for this amino acid. This feature was described previously for M. gudaonensis (Gu et al. 2007), and M. koreensi (Kim et al. 2006). With the present study, this characteristic is enlarged to at least 16 species and 4 potential novel ones. Furthermore this amino acid appeared to have an important physiological role due to the very high frequency of its utilization. Proline, is uncommon in proteins but has the characteristic to be compatible solute, that is to say, a molecule involved in resistance to the osmotic pressure, thermal stress for many heterotrophs (Welsh 2000). This ability could allow Marinobacter strains to resist to a wide range of physical parameters.

The main feature which emerges from the analyses of the substrates pattern is the capacity of many strains of Marinobacter to oxidize a very large spectrum of lipid molecules of various type and molecular weight (including Tween). This physiological aspect is not frequently explored in species characterization (Handley and Lloyd 2013). Degradation capacity towards tween is often reported in the literature due to its presence in Biolog panel. For example M. koreensis (Kim et al. 2006), M. lipolyticus strain SM19, M. litoralis (Martin et al. 2003) and M. bryozoorum or M. sediminum (Romanenko et al. 2005) were found positive. For other lipid molecules, except few studies, the degradation pattern toward these compounds remains often untested. $M$. 
hydrocarbonoclasticus is may be one of the best characterized. It can utilize $n$-alkanes ranging from $\mathrm{C}_{6}-\mathrm{C}_{30}$ (Doumenq et al. 2001; Duran 2010; Grimaud 2010 ). This trait seemed largely shared since genomic approach has highlighted the presence of alkane mono-oxygenase, an enzyme responsible for the first step oxidation of fatty acyl hydrocarbon in 15 out of 16 genomes. According to literature, 9 Marinobacter species were identified as hydrocarbon degraders (Handley and Lloyd 2013); our results have identified 9 additional species. This feature was observed for strains isolated from environment enriched with petroleum such as oil producing well in the case of $M$. hydrocarbonoclasticus VT8 but was also observed for strains retrieved from potential petroleum-free samples such as dinoflagelates cultures for $M$ algicola (Green et al. 2006), or microbial mat for the two other genomes affiliated to M algicola (HL-58 and MCTG268), marine particles for M. adhaerens (Gärdes et al 2010) or Artic ocean sediment for M. psychrophilus BSs20148 (Song et al. 2013) for examples. Usually when hydrocarbon utilization is included in physiological characterization, only short chain hydrocarbon are tested. For screening the capacity to degrade long -chain alkanes with more than 18 carbon atoms, the use of almA gene has been recently suggested by Wang and Shao (Wang and Shao 2012). Strains belonging to $M$ koreensis, $M$ alkaliphilus, M. lipolyticus,M. flavimaris and $M$ hydrocarbonoclasticus were found positive by these authors (Wang and Shao 2012). This gene was recovered by specific BlastP on most genomes of our set and this trend was extended to species M. adhaerens, M. manganoxydans, M. algicola, M. daepoensis, M. santoriniensis, M. nanhaiticus, and M. excellens. In this study, the panel of electron donors include short and long chain hydrocarbons but also non-hydrocarbon lipids (glycerolipids). Most of the strains appeared positive. The results of this study highlighted also the need to screen several strains of a same species to find common physiological traits within a species. From previous studies (Timmis 2010 for a review), some Marinobacter type strains were described as short chain alkane degraders, this trend could now be expanded through a larger number of species including several strains within a species and to large spectrum of lipid molecules. These compounds appeared as preferred electron donors for Marinobacter species included in this set.

This capacity could account for the 10 fold increase of Marinobacters abundance in mesocosm contaminated with petroleum of this study. This value is higher than the 2 fold increase observed in anaerobic mesocosm with a CARD-FISH probe exploring only $26 \%$ of Marinobacter sequence (Genovese et al. 2014) but are in agreement with augmentation of Marinobacter ribosomal sequences found by pyrosequencing before and after oil pollution in mangrove (dos Santos et al. 2011). In our study, Marinobacter reached about $0.3 \%$ of the bacterial community in mesocosms containing hydrocarbon which is lower than the value found with less specific probe in anaerobic mesocosm by Genovese et al. (2014). However comparison between different studies should be taken with caution since other factors could be involved such as sensitivity to the load of petroleum or the selection of some species not detected by qPCR or CAR-FISH or a kinetic effect. The highest abundance of Marinobacter was observed in presence of petroleum and burrowing macrofauna. The presence and activity of burrowing macrofauna such as $H$. diversicolor, in sediment can significantly affect the 
repartition of electron acceptors and nutrient availability (Banta and Andersen 2003). In marine sediment, oxygen rapidly decreases with depth but several alternative electron acceptors are available. In absence of oxygen, nitrate is the most favorable electron acceptor since its reduction to $\mathrm{N}_{2}$ yields almost as much energy as aerobic respiration (Canfield et al. 2005). However nitrate concentrations in sediments are low probably due to low in situ production or rapid turnover. Bioturbation by macrofauna can enhance oxygen supply to deeper layers, favoring activity of nitrifying prokaryotes than can provide nitrate for nitrate respiring organisms (Laverock et al. 2011) such as denitrifiers. Some strains of Marinobacter have been shown as able to respire inorganic compounds such as arsenic (Handley et al 2013) or more frequently nitrate (i.e; denitrifier (Bonin et al. 1987; Gilewicz et al. 1997; Rontani et al. 2002; Goregues et al. 2004). The use of molecular technics has shown that narG, nirS and nos $Z$ are present in most of the nitrate reducers included in this study. These genes are frequently identified in genomes also. The denitrification property of type strain of $M$. pelagius, $M$. maritimus and M.vinifirmus was either incomplete or negative in previous studies. Our results have shown that at least some member of these species can perform this process. The impact of oil on denitrifying community was also addressed in this study. This community was enumerated with nos $Z$ as validated earlier (Rontani et al. 2010; Fernandes et al. 2012; Nogales et al. 2002). This gene was preferred to nirS since it presents the advantage to be the sole one coding for this enzymatic step. The percentage of nosZ-harboring cells increased under hydrocarbon amendment suggesting a probable role in petroleum degradation. Indeed some studies on isolated strains have reported the property of some Marinobacter to degrade hydrocarbon in anaerobiosis (Rontani et al. 2002).

From the results obtained in this study, primers amplifying a broader spectrum of Marinobacter ribosomal gene have confirmed the increasing prevalence of this genus when confronted with petroleum in mesocosms as previously observed with other technics. This phenomenon seems to be due to the pattern of electron donors of this genus, presenting a large range of lipid compounds and narrow ones with other organic molecules. This result has been confirmed by screening of several species and several strains within a species. Marinobacter development in sediment contaminated by petroleum was favored by burrowing macrofauna which facilitate diffusion of oxygen but also the supply nitrate to denitrifiers, some of whom belonging to Marinobacter genus. The high frequency of genes involved in alkane degradation of this genus would favor the utilization of this genus as proxy of petroleum monitoring. For example, their occurrence in surrounding area of hydrothermal vents (Wang et al 2012; Handley et al 2013) could be an indication of the diffusion of hydrocarbon effluents. However, the increase of Marinobacter in presence to oil pollution could be also the result of an opportunistic physiological trait toward lipid substrates.

\section{Acknowledgement}

This work was supported by ANR (DECAPAGE ANR-11-CESA-0006) 
We thank the captain and shipboard crew of R/V Pelagia and scientific crew. Furthermore, we acknowledge the Royal Netherlands Institute for Sea Research (NIOZ) for the support by the NIOZ-Marine Research Facilities (MRF) on-shore and on board.

Figure captions

Fig.1 Abundance of ribosomal 16S rRNA gene from bacteria or Marinobacter, and of nitrous oxide reductase gene (nosZ) in mesocosm in presence of Hydrocarbon or of burrowing macrofauna (H. diversicolor)

Neither Hydrocarbon amendment nor $H$. diversicolor addition (-HC-N), no Hydrocarbon amendment and $H$. diversicolor addition $(-\mathrm{HC}+\mathrm{N})$, hydrocarbon amendment and no $H$. diversicolor addition ( $+\mathrm{HC}-\mathrm{N})$, hydrocarbon amendment and $H$. diversicolor addition $(+\mathrm{HC}+\mathrm{N})$; These values mean the average number of genes detected in triplicated mesocosms. Several subsamples were collected from each mesocosm.

Fig.2 Main electron donors pattern of 10 taxa of Marinobacter, expressed as percentage of positive strains among a taxon. Substrates tested: 30 carbohydrates, 19 AA, 30 organic acids, 12 lipid molecules and 17 other compounds, only relevant results were indicated

\section{references}

Abed RMM, Zein B, Al-Thukair A, de Beer D (2007) Phylogenetic diversity and activity of aerobic heterotrophic bacteria from a hypersaline oil-polluted microbial mat. Syst Appl Microbiol 30: 319-330

Banta GT, Andersen O (2003) Bioturbation and the fate of sediment pollutants - Experimental case studies of selected infauna species. Vie Milieu 53: 233-248

Baumann P, Baumann L (1981) The marine gram negative eubacteria genus Photobacterium, Beneckea, Alteromonas, Pseudomonas and Alcaligenes. In: S-V K (Ed), The Prokaryotes: a handbook on habitats, isolation and identification of bacteria. Mortimer, P. S, New York, NY, pp. 1302-1330

Bonin P, Gilewicz M, Bertrand JC (1987) Denitrification by a Marine Bacterium Pseudomonas-Nautica Strain-617. Ann Inst Pasteur Mic 138: 371-383

Bonin P, Gilewicz M, Bertrand JC (1992) Effects of Oxygen on Pseudomonas-Nautica Growth on N-Alkane with or without Nitrate. Arch Microbiol 157: 538-545

Bordenave S, Goni-Urriza MS, Caumette P, Duran R (2007) Effects of heavy fuel oil on the bacterial community structure of a pristine microbial mat. Appl Environ Microb 73: 6089-6097

Bowman JP, McCammon SA, Brown MV, Nichols DS, McMeekin TA (1997) Diversity and association of psychrophilic bacteria in Antarctic sea ice. Appl Environ Microb 63: 3068-3078

Bowman JP, McMeekin TA (2005): Marinobacter. In: Brenner DJ, Krieg NR , Staley JT (Editors), Bergey's Manual of Systematic Bacteriology. Springer Science, New York, pp. 459-463 
Brito EM, Guyoneaud R, Goni-Urriza M, Ranchou-Peyruse A, Verbaere A, Crapez MAC, Wasserman JCA, Duran R (2006) Characterization of hydrocarbonoclastic bacterial communities from mangrove sediments in Guanabara Bay, Brazil. Res Microbiol 157: 752-762

Canfield DE, Jorgensen BB, Fossing H, Glud R, Gundersen J, Ramsing NB, Thamdrup B, Hansen JW, Nielsen LP, Hall POJ (1993) Pathways of Organic-Carbon Oxidation in 3 Continental-Margin Sediments. Mar Geol 113: 27-40

Canfield DE, Kristensen E, Thamdrup B (2005) Aquatic geomicrobiology. Adv Mar Biol 48: 1-599

Cui ZS, Lai QL, Dong CM, Shao ZZ (2008) Biodiversity of polycyclic aromatic hydrocarbon-degrading bacteria from deep sea sediments of the Middle Atlantic Ridge. Environ Microbiol 10: 2138-2149

Cui Z, Gao W, Xu G, Zheng L (2013) Genome sequence of the polycyclic aromatic hydrocarbon-degrading bacterium strain Marinobacter nanhaiticus D15-8WT Genome Announc . 1: e00301-13

Deppe U, Richnow HH, Michaelis W, Antranikian G (2005) Degradation of crude oil by an arctic microbial consortium. Extremophiles 9: 461-470

dos Santos HF, Cury JC, do Carmo FL, dos Santos AL, Tiedje J, van Elsas JD, Rosado AS, Peixoto RS (2011) Mangrove Bacterial Diversity and the Impact of Oil Contamination Revealed by Pyrosequencing: Bacterial Proxies for Oil Pollution. Plos One: 6

Doumenq P, Aries E, Asia L, Acquaviva M, Artaud J, Gilewicz M, Mille G, Bertrand JC (2001) Influence of n-alkanes and petroleum on fatty acid composition of a hydrocarbonoclastic bacterium: Marinobacter hydrocarbonoclasticus strain 617. Chemosphere 44: 519-528

Duran R (2010): Marinobacter. In: Timmis KN (Ed), Handbook of hydrocarbon and lipid microbiology. Springer-Verlag, Berlin Heidelberg, pp. 1725-1735

Edwards KJ, Rogers DR, Wirsen CO, McCollom TM (2003) Isolation and characterization of novel psychrophilic, neutrophilic, Fe-oxidizing, chemolithoautotrophic alpha- and, gamma-Proteobacteria from the deep sea. Appl Environ Microb 69: 2906-2913

Fernandes SO, Michotey VD, Guasco S, Bonin PC, Bharathi PAL (2012) Denitrification prevails over anammox in tropical mangrove sediments (Goa, India). Mar Environ Res 74: 9-19

Gärdes A, Kaeppel E, Shehzad A, Seebah S, Teeling H, Yarza P, Glöckner F, Grossart H, Ullrich M (2010) Complete genome sequence of Marinobacter adhaerens type strain (HP15) , a diatom-interacting marine microorganism. SIGS 3:97-107

Gauthier MJ, Lafay B, Christen R, Fernandez L, Acquaviva M, Bonin P, Bertrand JC (1992) MarinobacterHydrocarbonoclasticus Gen-Nov, Sp-Nov, a New, Extremely Halotolerant, Hydrocarbon-Degrading Marine Bacterium. Int J Syst Bacteriol 42: 568-576

Genovese M, Crisafi F, Denaro R, Cappello S, Russo D, Calogero R, Santisi S, Catalfamo M, Modica A, Smedile F, Genovese L, Golyshin PN, Giuliano L, Yakimov MM (2014) Effective bioremediation strategy for rapid in situ cleanup of anoxic marine sediments in mesocosm oil spill simulation. Front Microbiol: 5

Gilewicz M, Nimatuzahroh, Nadalig T, Budzinski H, Doumenq P, Michotey V, Bertrand JC (1997) Isolation and characterization of a marine bacterium capable of utilizing 2-methylphenanthrene. Appl Microbiol Biot 48: 528-533

Goregues C, Michotey V, Bonin P (2004) Isolation of hydrocarbonoclastic denitrifying bacteria from berre microbial mats. Ophelia 58: 263-270

Goregues CM, Michotey VD, Bonin PC (2005) Molecular, biochemical, and physiological approaches for understanding the ecology of denitrification. Microb Ecol 49: 198-208

Gorshkova NM, Ivanova EP, Sergeev AF, Zhukova NV, Alexeeva Y, Wright JP, Nicolau DV, Mikhailov VV, Christen R (2003) Marinobacter excellens sp nov., isolated from sediments of the Sea of Japan. Int J Syst Evol Micr 53: 2073-2078

Gray ND, Sherry A, Grant RJ, Rowan AK, Hubert CRJ, Callbeck CM, Aitken CM, Jones DM, Adams JJ, Larter SR, Head IM (2011) The quantitative significance of Syntrophaceae and syntrophic partnerships in methanogenic degradation of crude oil alkanes. Environ Microbiol 13: 2957-2975

Green DH, Bowman JP, Smith EA, Gutierrez T, Bolch CJS (2006) Marinobacter algicola sp nov., isolated from laboratory cultures of paralytic shellfish toxin-producing dinoflagellates. Int J Syst Evol Micr 56: $523-527$ 
Grimaud R (2010) Marinobacter. In: Timmis KN (Ed), Handbook of hydrocarbon and lipid microbiology. Springer-Verlag, Berlin Heidelberg, pp. 1289-1296

Grimaud R, Ghiglione JF, Cagnon C, Lauga B, Vaysse, PJ, Rodriguez-Blanco A, Mangenot A, Cruveiller S, Barbe V, Duran R, Wu LF, Talla E, Bonin P, Michotey V (2012) Genome sequence of the marine bacterium Marinobacter hydrocarbonoclasticus SP17 which forms biofilms on hydrophobic organic compounds. J Bacteriol 94:3539-40

Gu J, Cai H, Yu SL, Qu R, Yin B, Guo YF, Zhao JY, Wu XL (2007) Marinobacter gudaonensis sp nov., isolated from an oil-polluted saline soil in a Chinese oilfield. Int J Syst Evol Micr 57: 250-254

Handley KM, Lloyd JR (2013) Biogeochemical implications of the ubiquitous colonization of marine habitats and redox gradients by Marinobacter species. Front Microbiol 4

Handley KM, Upton M, Beatson S, Lloyd JR (2013) genome sequence of thermal arsenic -respiring bacterium Marinobacter santoriniensis NKSG1. Genome Announc 1:e00231-13

Huu NB, Denner EBM, Ha DTC, Wanner G, Stan-Lotter H (1999) Marinobacter aquaeolei sp. nov., a halophilic bacterium isolated from a Vietnamese oil-producing well. Int J Syst Bacteriol 49: 367-375

Karner M, Fuhrman JA (1997) Determination of active marine bacterioplankton: A comparison of universal 16S rRNA probes, autoradiography, and nucleoid staining. Appl Environ Microb 63: 1208-1213

Kim BY, Weon HY, Yoo SH, Kim JS, Kwon SW, Stackebrandt E, Go SJ (2006) Marinobacter koreensis sp nov., isolated from sea sand in Korea. Int J Syst Evol Micr 56: 2653-2656

Ladygina N, Dedyukhina E, Vainshtein M (2006) A review on microbial synthesis of hydrocarbons. Process Biochem 41:1001-1014

Lamendella R, Strutt S, Borglin S, Chakraborty R, Tas N, Mason OU, Hultman J, Prestat E, Hazen TC, Jansson JK (2014) Assessments of the Deepwater Horizon oil spill impact on Gulf coast microbial communities. Front Microbiol 5

Laverock B, Gilbert JA, Tait K, Osborn AM, Widdicombe S (2011) Bioturbation: impact on the marine nitrogen cycle. Biochem Soc T 39: 315-320

Lee OO, Lai PY, Wu HX, Zhou XJ, Miao L, Wang H, Qian PY (2012) Marinobacter xestospongiae sp nov., isolated from the marine sponge Xestospongia testudinaria collected from the Red Sea. Int J Syst Evol Micr 62: 1980-1985

Marquez MC, Ventosa A (2005) Marinobacter hydrocarbonoclasticus Gauthier et al. 1992 and Marinobacter aquaeolei Nguyen et al. 1999 are heterotypic synonyms. Int J Syst Evol Micr 55: 1349-1351

Martin S, Marquez MC, Sanchez-Porro C, Mellado E, Arahal DR, Ventosa A (2003) Marinobacter lipolyticus sp nov., a novel moderate halophile with lipolytic activity. Int J Syst Evol Micr 53: 1383-1387

Michotey V, Mejean V, Bonin P (2000) Comparison of methods for quantification of cytochrome cd(1)denitrifying bacteria in environmental marine samples. Appl Environ Microb 66: 1564-1571

Michotey V, Guasco S, Boeuf D, Morezzi N, Durieux B, Charpy L, Bonin P (2012) Spatio-temporal diversity of free-living and particle-attached prokaryotes in the tropical lagoon of Ahe atoll (Tuamotu Archipelago) and its surrounding oceanic waters. Mar Pollut Bull 65: 525-537

Mikucki JA, Priscu JC (2007) Bacterial diversity associated with blood falls, a subglacial outflow from the Taylor Glacier, Antarctica. Appl Environ Microb 73: 4029-4039

Nogales B, Timmis KN, Nedwell DB, Osborn AM (2002) Detection and diversity of expressed denitrification genes in estuarine sediments after reverse transcription-PCR amplification from mRNA. Appl Environ Microb 68: 5017-5025

Romanenko LA, Schumann P, Rohde M, Zhukova NV, Mkhailov VV, Stackebrandt E (2005) Marinobacter bryozoorum sp nov and Marinobacter sediminum sp nov., novel bacteria from the marine environment. Int J Syst Evol Micr 55: 143-148

Rontani JF, Gilewicz MJ, Michotey VD, Zheng TL, Bonin PC, Bertrand JC (1997) Aerobic and anaerobic metabolism of 6,10,14-trimethylpentadecan-2-one by a denitrifying bacterium isolated from marine sediments. Appl Environ Microb 63: 636-643

Rontani JF, Mouzdahir A, Michotey V, Bonin P (2002) Aerobic and anaerobic metabolism of squalene by a denitrifying bacterium isolated from marine sediment. Arch Microbiol 178: 279-287

Rontani JF, Nassiry M, Michotey V, Guasco S, Bonin P (2010) Formation of pristane from alpha-tocopherol under simulated anoxic sedimentary conditions: A combination of biotic and abiotic degradative processes. Geochim Cosmochim Ac 74: 252-263 
Rosch C, Mergel A, Bothe H (2002) Biodiversity of denitrifying and dinitrogen-fixing bacteria in an acid forest soil. Appl Environ Microb 68: 3818-3829

Seewald J (2003) Organic-inorganic interactions in petroleum-producing sedimentary basins. Nature 426:327333

Shieh WY, Jean WD, Lin YT, Tseng M (2003) Marinobacter lutaoensis sp nov., a thermotolerant marine bacterium isolated from a coastal hot spring in Lutao, Taiwan. Can J Microbiol 49: 244-252

Song L, Ren L, Li X, Yu D, Wang X, Liu G (2013) Complete genome sequence of Marinobacter sp.BSs20148. genom a Genome Announc 1:e00236-13

Sproer C, Lang E, Hobeck P, Burghardt J, Stackebrandt E, Tindall BJ (1998) Transfer of Pseudomonas nautica to Marinobacter hydrocarbonoclasticus. Int J Syst Bacteriol 48: 1445-1448

Stauffert M, Cravo-Laureau C, duran R (2014) Structure of hydrocarbonoclastic nitrate reducing bacterial communities in bioturbated coastal marine sediment. Fems Microbiol Ecol 89: 580-593

Takai K, Moyer CL, Miyazaki M, Nogi Y, Hirayama H, Nealson KH, Horikoshi K (2005) Marinobacter alkaliphilus sp nov., a novel alkaliphilic bacterium isolated from subseafloor alkaline serpentine mud from Ocean Drilling Program Site 1200 at South Chamorro Seamount, Mariana Forearc. Extremophiles 9: 17-27

Thane Papke R, de la Haba R, Infante-Domínguez C, Pérez D, Sánchez-Porro C, Lapierre P, Ventosa A (2013) Draft genome sequence of the moderately halophilic bacterium Marinobacter lipolyticus strain SM19. Genome Announc 1:e00379-13

Timmis KN (2010), Handbook of hydrocarbon and lipid microbiology. Springer-Verlag, Berlin Heidelberg,

Wang WP, Shao ZZ (2012) Diversity of flavin-binding monooxygenase genes (almA) in marine bacteria capable of degradation long-chain alkanes. Fems Microbiol Ecol 80: 523-533

Wang H, Li H, Shao Z, Liao S, Johnstone L, Rensing C, Wang G (2012) Genome sequence of deep-sea Manganese-oxidizing bacterium Marinobacter manganoxydans MnI7-9. J Bacteriol 194: 899-900.

Welsh DT (2000) Ecological significance of compatible solute accumulation by micro-organisms: from single cells to global climate. Fems Microbiol Rev 24: 263-290

Whiticar MJ, Suess E (1990) Hydrothremal hydrocarbon gases in the sediments of king George Basin, Branfield strait Antartica. Appl. Geochem. 5: 135-147

Yakimov MM, Giuliano L, Crisafi E, Chernikova TN, Timmis KN, Golyshin PN (2002) Microbial community of a saline mud volcano at San Biagio-Belpasso, Mt. Etna (Italy). Environ Microbiol 4: 249-256

Yoon JH, Yeo SH, Kim IG, Oh TK (2004) Marinobacter flavimaris sp nov and Marinobacter daepoensis sp nov., slightly halophilic organisms isolated from sea water of the Yellow Sea in Korea. Int J Syst Evol Micr 54: 1799-1803 


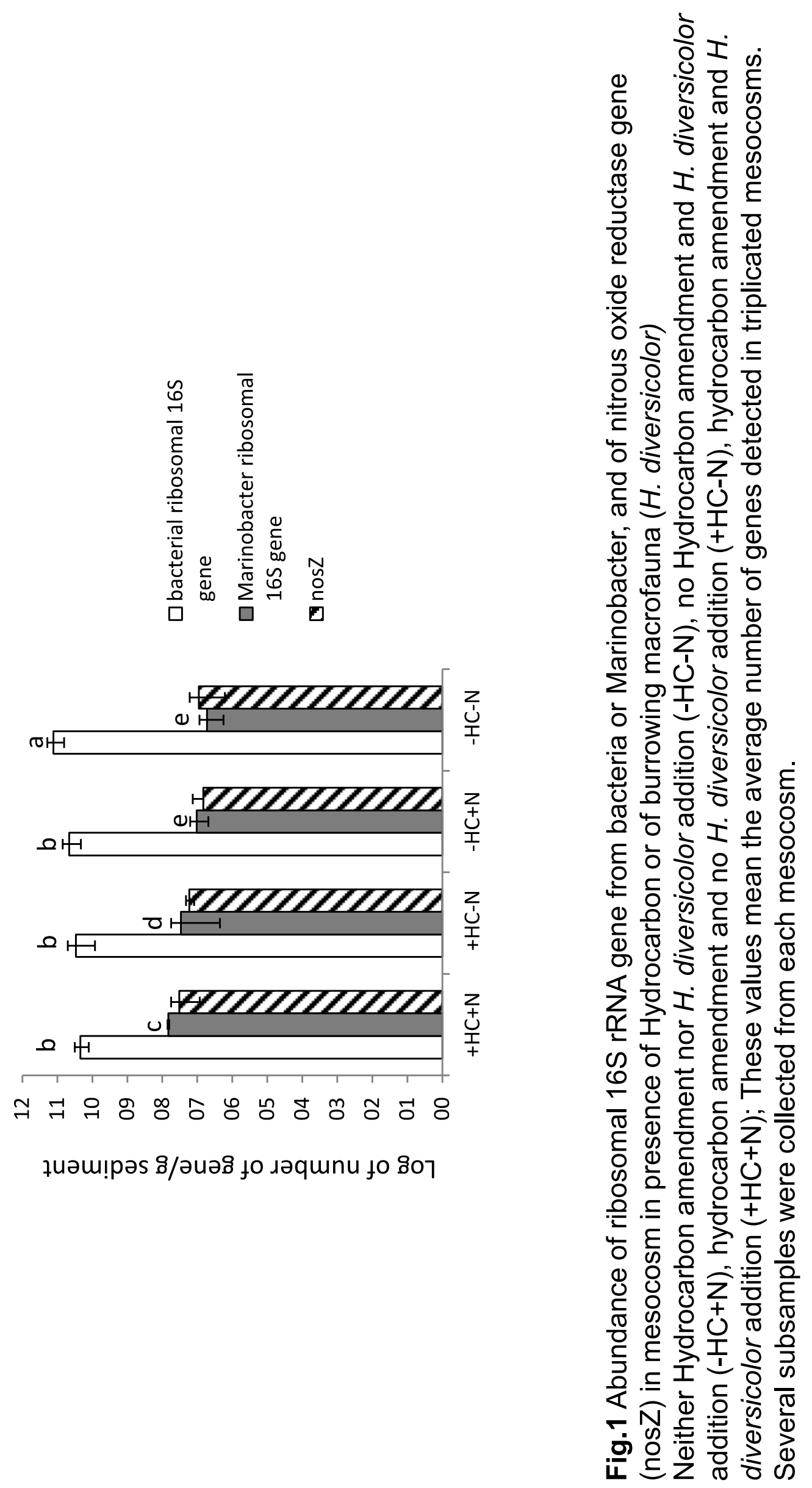




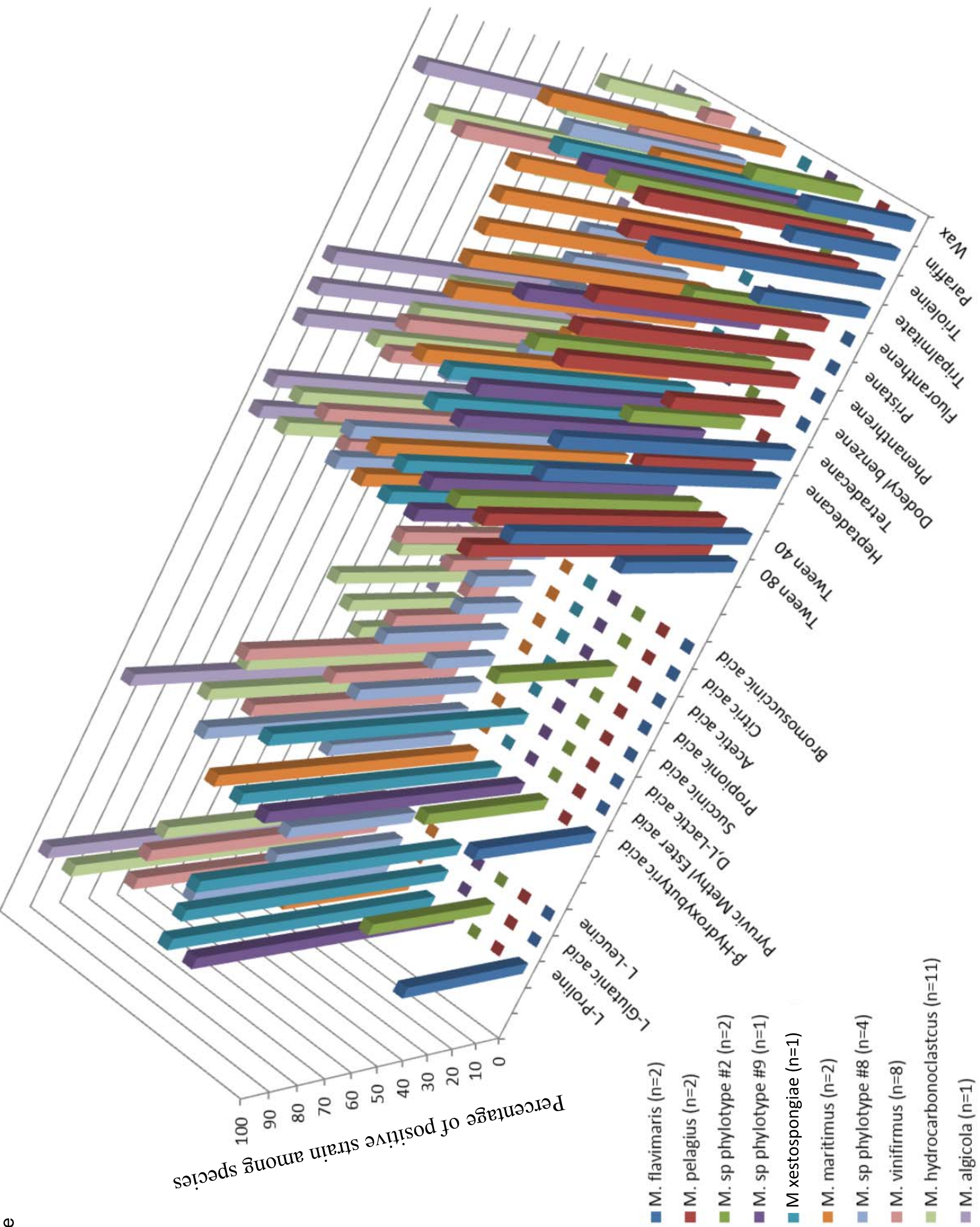




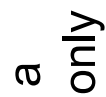

ס

드음

สิ

(⿻) 을

.

क

$\sum_{0}^{0}$

N

두

บ음

\%

전

당

ن

ํㅡㄹ

요 응

응

D

कै

읏 응

(1)

그으

ডั

응 잉

요

$\stackrel{\pi}{2}$

니으

(ब)

तु

0 त

능

등은

Ð

을

응 믕

응 쏘 을

ᄃㄴำ

क्रे

过

윽 일

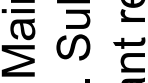

พ ᄃं

은 저 
Table 1 : list of Marinobacter strains used in this study

\begin{tabular}{|c|c|c|c|c|c|}
\hline species & strains & $\begin{array}{l}\text { Location of } \\
\text { isolation }\end{array}$ & Type of sample & reference & $\begin{array}{c}\text { Physiological }(\mathrm{P}), \\
\text { genomic }(\mathrm{G}) \\
\text { analysis }\end{array}$ \\
\hline \multirow{6}{*}{$\begin{array}{c}M . \\
\text { hydrocarbonoclasticus }\end{array}$} & $\begin{array}{c}\text { VT8, DSM } \\
11845^{*}\end{array}$ & Vietnam & $\begin{array}{l}\text { Oil producing } \\
\text { well }\end{array}$ & (Huu et al. 1999) & $P, G$ \\
\hline & DN1* & $\begin{array}{c}\text { Gulf of Fos, } \\
\text { Med Sea }\end{array}$ & sediment & (Bonin et al. 1987) & $\mathrm{P}$ \\
\hline & $\begin{array}{c}17 \\
\text { ATCC } 49840\end{array}$ & $\begin{array}{l}\text { Gulf of Fos, } \\
\text { Med Sea }\end{array}$ & sediment & (Gauthier et al. 1992) & $P, G$ \\
\hline & $\mathrm{CAB}$ & $\begin{array}{l}\text { Gulf of Fos, } \\
\text { Med Sea }\end{array}$ & sediment & (Gilewicz et al. 1997) & $\mathrm{P}$ \\
\hline & $\begin{array}{l}\mathrm{BC} 36, \mathrm{BC} 38 \\
\mathrm{R} 153\end{array}$ & $\begin{array}{c}\text { Berre } \\
\text { lagoon, } \\
\text { Med Sea }\end{array}$ & sediment & (Goregues et al. 2004) & $\mathrm{P}$ \\
\hline & $\begin{array}{c}\text { 23W2B, } \\
\text { CUBW5A, } \\
\text { CUBW5B, } \\
23 \text { tet5B }\end{array}$ & North Sea & Water column & This study & $P$ \\
\hline M. vinifirmus & $\begin{array}{l}\text { BC45, NBC44, } \\
\text { NBC35, NBC34, } \\
\text { NBC33, NBC32, } \\
\text { BC43, BC34 }\end{array}$ & $\begin{array}{l}\text { Berre } \\
\text { lagoon, } \\
\text { Med Sea }\end{array}$ & sediment & (Goregues et al. 2004) & $\mathrm{P}$ \\
\hline M. maritimus & $2 \mathrm{Sq} 31,1 \mathrm{sq} 53$ & $\begin{array}{l}\text { Gulf of Fos, } \\
\text { Med Sea }\end{array}$ & sediment & (Rontani et al. 2002) & $\mathrm{P}$ \\
\hline $\begin{array}{c}\text { M. flavimari } \\
\text { M. adhaerens } \\
\text { M. manganoxydans }\end{array}$ & $\begin{array}{c}\text { Cubtrip2B, } \\
\text { Cubtet1B }\end{array}$ & North Sea & Water column & This study & $\mathrm{P}$ \\
\hline M. adhaerens & $\begin{array}{c}H P 15 D S M \\
23420\end{array}$ & $\begin{array}{c}\text { German } \\
\text { Wadden } \\
\text { Sea } \\
\end{array}$ & $\begin{array}{l}\text { Diatom } \\
\text { interaction }\end{array}$ & (Gärdes et al 2010) & G \\
\hline M. manganoxydans & $M n I 7-9$ & $\begin{array}{l}\text { Indian } \\
\text { Ocean }\end{array}$ & $\begin{array}{c}\text { deep-sea } \\
\text { hydrothermal } \\
\text { vent sediment }\end{array}$ & (Wang et al 2012) & G \\
\hline M. pelagius & R171, R42 & $\begin{array}{c}\text { Berre } \\
\text { lagoon, } \\
\text { Med Sea }\end{array}$ & sediment & (Goregues et al. 2004) & $\mathrm{P}$ \\
\hline \multirow{3}{*}{ M. algicola } & DG893 & culture & dinoflagellates & (Green et al. 2006) & $\mathrm{P}, \mathrm{G}$ \\
\hline & $H L-58$ & - & Microbial mat & unpublished & G \\
\hline & MCTG268 & - & Microbila mat & unpublished & G \\
\hline$M$. xestospongiae & BP42 & $\begin{array}{c}\text { Berre } \\
\text { lagoon, } \\
\text { Med Sea }\end{array}$ & sediment & (Goregues et al. 2004) & $\mathrm{P}$ \\
\hline M. daepoensis & $\begin{array}{c}S W-156^{T}(D S M \\
16072\end{array}$ & $\begin{array}{l}\text { South } \\
\text { Korea }\end{array}$ & Water column & (Yoon et al 2004) & G \\
\hline M. santoriniensis & $N K S G 1$ & $\begin{array}{l}\text { Santorini, } \\
\text { Med Sea }\end{array}$ & $\begin{array}{l}\text { Shallow } \\
\text { marine } \\
\text { hydrothermal } \\
\text { sediment; }\end{array}$ & (Handley et al 2013) & G \\
\hline M. lipolyticus & SM19 & Spain & saline soil & (Papke et al 2013) & G \\
\hline
\end{tabular}




\begin{tabular}{|c|c|c|c|c|c|}
\hline & BF04_CF-4 & - & - & unpublished & $\mathrm{G}$ \\
\hline M. nanhaiticus & D15-8W & $\begin{array}{c}\text { South } \\
\text { China Sea }\end{array}$ & Sediment & (Cui et al 2013) & G \\
\hline M. excellens & HL-55 & - & - & unpublished & $\mathrm{G}$ \\
\hline \multirow[t]{2}{*}{ M. psychrophilus } & ELB17 & Antarctica & $\begin{array}{c}\text { waters of a } \\
\text { permanently } \\
\text { ice-covered } \\
\text { lake }\end{array}$ & unpublished & $\mathrm{G}$ \\
\hline & BSs20148 & $\begin{array}{l}\text { Arctic } \\
\text { Ocean }\end{array}$ & sediment & (Song et al 2013) & G \\
\hline M. strain $A K 21$ & AK21 & India & Water column & unpublished & G \\
\hline$M$. sp. phylotype \#2 & BP45, NBP42 & $\begin{array}{c}\text { Berre } \\
\text { lagoon, } \\
\text { Med Sea }\end{array}$ & sediment & (Goregues et al. 2004) & $\mathrm{P}$ \\
\hline$M$. sp. phylotype \#8 & $\begin{array}{c}\text { U32, S64, T33, } \\
\text { U31 }\end{array}$ & $\begin{array}{c}\text { Berre } \\
\text { lagoon, } \\
\text { Med Sea }\end{array}$ & sediment & (Goregues et al. 2004) & $\mathrm{P}$ \\
\hline M. sp. phylotype \#9 & R53 & $\begin{array}{c}\text { Berre } \\
\text { lagoon Med } \\
\text { Sea }\end{array}$ & sediment & (Goregues et al. 2004) & $P$ \\
\hline
\end{tabular}

* Pseudomonas nautica (DN1) (Sproer et al. 1998) and Marinobacter aquaeolei (VT8) ((Marquez \&Ventosa 2005) are synonymous with the type species Marinobacter hydrocarbonoclasticus (Gauthier et al. 1992) 
Table 2 Comparison of different PCR primers or probes for detection of Marinobacter 16S rDNA using probe-match (RDP probe match tool)

\begin{tabular}{|c|c|c|c|}
\hline Primer set & $\begin{array}{c}\text { Marinob300F-Marinob600R } \\
\text { Number of hits (\% recovery) }\end{array}$ & $\begin{array}{c}\text { Mab451f-Mab573r } \\
\text { Number of hits } \\
\text { (\% recovery) }\end{array}$ & $\begin{array}{c}\text { CARD-FISH probe } \\
\text { Number of hits } \\
\text { (\% recovery) }\end{array}$ \\
\hline reference & This study & (Gray et al. 2011) & $\begin{array}{c}\text { (Karner \&Fuhrman } \\
1997)\end{array}$ \\
Bacteria & $2414 / 2879170$ & $242 / 2879170$ & $885 / 2879170$ \\
$\begin{array}{c}\text { Marinobacter genus } \\
\text { Marinobacter type } \\
\text { strains }\end{array}$ & $2374 / 3639(64.5 \%)$ & $235 / 3639(6.4 \%)$ & $714 / 3639(20.6 \%)$ \\
Non-target matches & $27 / 30(90 \%)$ & $1 / 30(3 \%)$ & $8 / 30(26.6 \%)$ \\
\hline
\end{tabular}


Table 3: Main features of Marinobacter capacity to use electron donors and acceptors from the analysis of 16 genomes with the focus on external transporters or crucial enzymatic steps.

\begin{tabular}{|c|c|c|}
\hline Classification & name & $\begin{array}{l}\text { Number of positive } \\
\text { genomes out of } 16\end{array}$ \\
\hline \multicolumn{3}{|c|}{ Carbohydrate, organic alcohol and acids transport } \\
\hline TIGR00786 & TRAP transporter, DctM subunit (malate, fumarate, succinate) & 16 \\
\hline TIGR00795 & L-lactate transport & 5 \\
\hline TIGR00792 & sugar (Glycoside-Pentoside-Hexuronide) transporter & 0 \\
\hline TIGR01003 & Phosphotransferase System HPr (HPr) Family & 16 \\
\hline TIGR00822 & PTS system, mannose/fructose/sorbose family, IIC component & 0 \\
\hline TIGR00410 & PTS system, lactose/cellobiose family IIC component & 0 \\
\hline TIGR00821 & PTS system, glucitol/sorbitol-specific, IIC component & 0 \\
\hline TIGR00852 & $\begin{array}{c}\text { PTS system, maltose and glucose-specific subfamily, IIC } \\
\text { component }\end{array}$ & 0 \\
\hline \multicolumn{3}{|c|}{ AA transport } \\
\hline TIGR02121 & sodium/proline symporter & 16 \\
\hline TIGR00814 & serine transporter & 0 \\
\hline TIGR00837 & aromatic amino acid transport protein & 0 \\
\hline TIGR00905 & transporter, basic amino acid/polyamine antiporter (APA) family & 1 \\
\hline TIGR00950 & Carboxylate/Amino Acid/Amine Transporter & 16 \\
\hline TIGR00906 & cationic amino acid transport permease & 0 \\
\hline \multicolumn{3}{|c|}{ Lipid degradation } \\
\hline TIGR02437 & fatty oxidation complex, alpha subunit FadB & 16 \\
\hline TIGR02445 & fatty oxidation complex, beta subunit FadA & 16 \\
\hline$E C: 1.14 .15 .3$ & Alkane 1-monooxygenase. AlkA & 15 \\
\hline$E C: 1.14 .13 .8$ & flavin-binding monooxygenase AlmA & 13 \\
\hline$E C: 3.8 .1 .5$ & Haloalkane dehalogenase. & 14 \\
\hline \multicolumn{3}{|c|}{ Nitrate respiration/denitrification } \\
\hline TIGR01706 & periplasmic nitrate reductase, large subunit NapA & 2 \\
\hline TIGR02161 & $\begin{array}{l}\text { periplasmic nitrate (or nitrite) reductase c-type cytochrome, } \\
\text { NapC/NirT family NirS }\end{array}$ & 4 \\
\hline TIGR02376 & nitrite reductase, copper-containing, nirK & 4 \\
\hline TIGR04244 & nitrous-oxide reductase, TAT-dependent NosZ & 10 \\
\hline
\end{tabular}

Genome list: M. adhaerens, $M$. algicola, $M$ hydrocarbonoclasticus VT8, $M$. hydrocarbonoclasticus $\mathrm{sp} 17, M$ excellens, M. daepoensis, M. lipolyticus BF04, M. lipoliticus SM14, M. maganoxydans, M. nanhaiticus, $M$. santoriniensis, $M$. sp AK21, M. sp. BSs20148, M. sp. ELB17, M. sp. MCTG268, M. sp. HL-58 
Table 4 denitrifying strains among Marinobacter set and presence of 3 out of the 4 steps of denitrification

\begin{tabular}{|c|c|c|c|c|c|c|c|c|}
\hline & 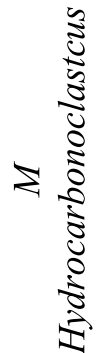 & 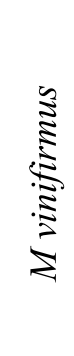 & 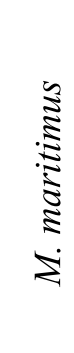 & 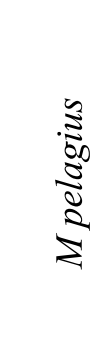 & 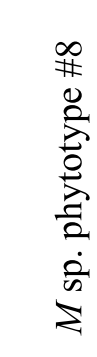 & 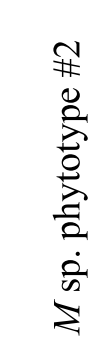 & 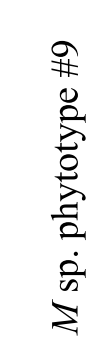 & 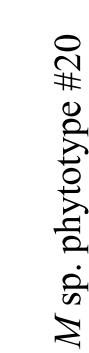 \\
\hline & $\mathrm{n}=6^{1}$ & $\mathrm{n}=8$ & $\mathrm{n}=2$ & $\mathrm{n}=2$ & $\mathrm{n}=4$ & $\mathrm{n}=2$ & $\mathrm{n}=1$ & $\mathrm{n}=1$ \\
\hline Denitrification* & 6 & 7 & 1 & 2 & 3 & 1 & 1 & 1 \\
\hline$n a r G$ & 6 & 5 & 2 & 2 & 4 & 2 & 1 & 1 \\
\hline $\operatorname{nir} S$ & 6 & 7 & 2 & 2 & 3 & 2 & 1 & 1 \\
\hline $\operatorname{nos} Z$ & 6 & 7 & 2 & 2 & 4 & 1 & 1 & 1 \\
\hline
\end{tabular}

Denitrification property were determined previously (Bonin et al. 1987, 1992, Goregues et al. 2004, Rontani et al. 1997)

Data concerning nitic oxide reductase (NorB) are not available

${ }^{1} \mathrm{DN} 1, \mathrm{Sp} 17, \mathrm{CAB}, \mathrm{BC} 36, \mathrm{BC} 38, \mathrm{R} 153$ 


\section{Substrate utilization profile of Marinobacter genus indicates a specialization in lipid compounds including hydrocarbons}

Patricia Bonin ${ }^{1}$, Christophe Vieira ${ }^{1,2}$, Régis Grimaud ${ }^{3}$, Cécile Militon ${ }^{1}$, Philippe Cuny ${ }^{1}$, Oscar Lima ${ }^{1,4}$, Sophie Guasco, Corina P.D. Brussaard ${ }^{5}$, Valérie Michotey ${ }^{1 *}$,

1: Aix Marseille Université, CNRS, Université de Toulon, IRD, MIO UM 110, 13288, Marseille, France

2: present adress : Sorbonne Universités, UPMC Univ Paris 06, IFD, 4 Place Jussieu, 75252 PARIS cedex 05, France

3: Institut Pluridisciplinaire de Recherche en Environnement et Matériaux, Equipe Environnement et Microbiologie, UMR 5254, CNRS, IBEAS, Université de Pau et des Pays de l'Adour, Pau, France

4 : present adress Ecosystèmes, biodiversité, évolution (ECOBIO), CNRS : UMR6553 - Université de Rennes 1 - INEE - Observatoire des Sciences de l'Univers de Rennes, France

5: Royal Netherlands Institute for Sea Research, Department of Biological Oceanography NL-1790 AB Den Burg, Netherlands

*Corresponding author: Valerie michotey, valerie.michotey@univ-amu.fr

Address: Campus de Luminy, case 901, av de Luminy, 13288 Marseille Cedex , France, (33(0)491829623)

Keywords: Marinobater, Hydrocarbon, marine sediment, quantification, electron donor pattern, denitrification

Abstract: The impact of petroleum contamination and of burrowing macrofauna on abundances of Marinobacter and denitrifiers was tested in marine sediment mesocoms after 3 months incubation. Quantification of this genus by qPCR with a new primer set showed that the main factor favoring Marinobacter abundance was hydrocarbon amendment followed by macrofauna presence. In parallel, proportion of nosZ-harbouring bacteria increased in the presence of marcrofauna. Quantitative finding were explained by physiological data from a set of 34 strains and by genomic analysis of 16 genomes spanning 15 different Marinobacter validated species (M. hydrocarbonoclasticus, M.daeopensis, M. santoriniensis, M. pelagius, M. flavimaris, M. adhaerens, M. xestospongiae, M. algicola, M. vinifirmus; $M$. maritimus, $M$. psychrophilus, M. lipoliticus, M. manganoxydans, , M. excellens, M. nanhaiticus) and 4 potential novel ones. Among the 105 organic electron donors tested in physiological analysis, Marinobacter pattern appeared narrow for almost all kinds of organic compounds except lipid ones. Strains of this set could oxidize a very large spectrum of lipids belonging to glycerolipids, branched-, fatty acyls-, and aromatic hydrocarbon classes. Physiological data were comforted by genomic analysis and genes of alkane 1-monooxygenase, haloalkane dehalogenase and flavin-binding monooxygenase were detected in most genomes. Denitrification was assessed for several strains belonging to $M$. hydrocarbonoclasticus, $M$. vinifirmus, M. maritinus, M. pelagius species indicating the possibility to use nitrate as alternative electron acceptor. Higher occurrence of Marinobacter in presence of petroleum appeared to be the result of a broader physiological trait allowing this genus to use lipids including hydrocarbon as principal electron donors. 


\section{Introduction}

The Marinobacter genus was first described in 1992 (Gauthier et al. 1992) and belongs to the $\gamma$ Proteobacteria class and the Alteromonadaceae family. They are Gram negative and mostly facultative aerobic heterotrophic bacteria. The genus includes 30 Marinobacter species currently validated. Some of them can grow anaerobically by nitrate reduction $(20 / 30)$ and some of them $(6 / 30)$ have been further characterized as denitrifiers (able to perform reduction of nitrate to $\mathrm{N}_{2}$ by respiratory process) (Handley and Lloyd 2013)

Presently, more than 3871 sequences of 16S rRNA genes affiliated to the genus Marinobacter are available in the RDP ribosomal database from either isolates or clone strains. Heighten genomes are deposited in different banks. Bacteria belonging to genus Marinobacter are commonly detected in diverse marine environments such as coastal marine sediments (Gauthier et al. 1992; Gorshkova et al. 2003), waters (Yoon et al. 2004), and sea sand environments (Kim et al. 2006), deep-water sediments (Cui et al. 2008; Edwards et al. 2003) hydrothermal vents (Shieh et al. 2003), mud volcanoes (Yakimov et al. 2002), hypersaline microbial mats (Abed et al. 2007; Bordenave et al. 2007), sediments of mangrove (Brito et al. 2006), alkaline seabed (Takai et al. 2005), sea ice of the Arctic (Deppe et al. 2005) or the Antarctica (Bowman et al. 1997; Mikucki and Priscu 2007), sediments of the deep Arctic waters (Martin et al. 2003). Representatives of this genus have also been identified associated with the bacterial flora of marine organisms. Indeed, they were isolated from photosynthetic unicellular organisms such as dinoflagellates secreting paralyzing toxins (Gymnodinium catenatum and Alexandrium tamarense) (Green et al. 2006) as well as multicellular organisms such as bryozoans (Romanenko et al. 2005) and sponges (Lee et al. 2012). Thus Marinobacter seems to colonize a wide variety of marine ecosystems around the world ranging from psychrophilic to thermophilic environments with a high tolerance to salinity and $\mathrm{pH}$. Their ability to occupy diverse physicochemical regimes seems an indication of large phenotypic versatility.

Recently metagenomic analyses have highlighted the presence of Marinobacter sequences at relatively high percentage in oil polluted environments. Ribosomal or denitrifying genes affiliated to the genus Marinobacter have been identified in oil spill simulation mesocosms with marine coastal sediment (Stauffert et al. 2014), estuarine sediment (Gray et al. 2011) or mangrove sediment (dos Santos et al. 2011). Metatranscriptomic analysis revealed that strains belonging to Marinobacter genus are active in polluted environments. In a study on the Deep Horizon spill, Marinobacter aquaolei strain VT8 genome (now affiliated with $M$ hydrocrabonoclasticus) was the closest match to metatranscriptomes (Lamendella et al. 2014). Moreover, in anoxic mesocosm, Marinobacter strain alkB cDNA, coding for a hydroxylase involved in degradation of short-chain alkanes, has been quantitatively detected by qPCR (Genovese et al. 2014). These results led some authors to propose the use of sequences of the genus Marinobacter as one of the proxies for oil pollution monitoring (dos Santos et al. 2011; Genovese et al. 2014; Gray et al. 2011). Molecular approaches alone are 
however, unable to establish a relationship between the presence of a genus and its real ecophysiological role in the studied ecosystem. In order to tackle this drawback, it is necessary to complement molecular information with physiological data on hydrocarbon degradation capacities of strains belonging to different Marinobacter species. Although the properties towards hydrocarbon degradation of some type strains have been investigated (for a review see (Duran 2010), it should extend to more strains and to several isolates of the same species. In a broader approach, the determination of the ecological role of Marinobacter needs further investigation on their electron donor pattern.

With the exception of the most superficial layer, bulk of marine sediments are assumed to be anoxic (Canfield et al. 1993) especially when contaminated with hydrocarbons due to the reduction of oxygen diffusion. The ability to use alternative electron acceptors is then an ecological advantage for bacterial communities. The capability to perform nitrate reduction in anaerobiosis has been frequently reported for Marinobacter and denitrification for at least some strains. This feature need also to be further explored.

This study intends to analyze the robustness of Marinobacter proxy as hydrocarbon pollution applying genus dynamic in the face of oil contamination, physiological analysis toward hydrophobic and hydrocarbons compounds and anaerobic respiration. Their dynamic upon contamination with petroleum has been investigated by qPCR with new primer set, in marine sediment mesocosms. Due to the impact of burrowing macrofauna on oxygen supply and on in situ nitrate production resulting of the activity of nitrifying prokaryotes, this condition has been also tested. In parallel investigations on the physiological characteristics of Marinobacter has been undertaken with 34 isolates pertaining to 7 validated species and 3 potential novel ones in order to determine their spectrum of electron donors and their potentiality regarding denitrification. The analysis of 16 genomes has permitted to enlarge these observations to 8 additional validated species and to one potential novel one.

\section{Materials and Methods}

Bacterial strains and isolation procedures: The bacterial strains studied belong to the genus Marinobacter. The set of strain comprised collection strains (M. hydrocarbonuclasticus, M. aquaolei, M.algicola) and strains isolated from previous studies from Mediterranean sediments (Bonin et al. 1987; 1992; Goregues et al. 2004; Rontani et al. 1997) (Fig. 1).

Other strains $(23 w 2 b, 23 t e t 5 b$, cubw5a, cubw5b, cubtrip $2 b$ and cubtet $1 b)$ have been isolated in the frame of this study from North Sea water (Fig. 1). Samples were collected on board the RV Pelagia during May 2008. Strains $23 \mathrm{w} 2 \mathrm{~b}, 23 \mathrm{tet} 5 \mathrm{~b}$ were isolated from samples of surface water contaminated by an oil slick collected at $53^{\circ} 45^{\prime} 50.4^{\prime \prime N} 4^{\circ} 11^{\prime} 15.7914 " E$. Strains, cubw5a, cubw5b, cubtrip2b and cubtet1b were isolated from samples retrieved from a $1 \mathrm{~m}^{3}$ on-board mesocosm filled with seawater collected at $55^{\circ} 8^{\prime} 23.208^{\prime \prime} \mathrm{N}^{\circ} 11^{\prime}$ 
9.672" E at $29 \mathrm{~m}$ deep and contaminated with crude oil. Mesocosm were incubated seven days at ambient temperature on the deck before sampling for strain isolation. Seawater samples, either from sea or mesocosms were used to inoculate enrichment cultures in ASW (Baumann and Baumann 1981) containing tetradecane, paraffin or tripalmitate as sole carbon source. Colonies isolation was performed on agar ASW plates with acetate lactate glucose and yeast extract as carbon sources.

Electron donors screening: Electron donors were tested with Biolog GN microplates (Biolog TNC, Hayward, CA,USA). Cells were grown in ASW containing ammonium $(1 \mathrm{~g} / \mathrm{L})$ and a mixture of different carbon sources (lactate $1 \mathrm{~g} / \mathrm{L}$, acetate $1 \mathrm{~g} / \mathrm{L}$, glucose $1 \mathrm{~g} / \mathrm{L}$, yeast extract $2 \mathrm{~g} / \mathrm{L}$, peptone $2 \mathrm{~g} / \mathrm{L}$ ). Cultures in exponential phase of growth were pelleted, washed once in ASW without carbon source. Biolog GN microplates were inoculated with the cell suspensions as described in the manufacturer instructions. Utilization of carbon sources was detected as an increase in the respiration rate of cells in the well of a microplate, leading to irreversible reduction of the tetrazolium dye INT [2-(p-iodopheny)-3-(p-nitropheny)-5-phenyl tetrazolium chloride]. A positive utilization reaction was indicated when a purple color formed due to INT-formazan formation in a well after one week incubation at $20^{\circ} \mathrm{C}$. Biolog GN microplates contained the following carbon sources that could be used as electron donor in aerobiosis: 30 carbohydrates ( $\alpha$-Cyclodextrin, Dextrin, Glycogen, N-Acetyl-D-Galactosamine, N-Acetyl-D-Glucosamine, Adonitol, L-Arabinose, D-Arabitol, DCellobiose, i-Erythritol, D-Fructose, D-Fucose, D-Galactose, Gentiobiose, $\alpha$-D-Glucose, $\alpha$-D-Lactose, Lactulose, Maltose, D-Mannitol, D-Mannose, D-Melibiose, $\beta$-Methyl-D-Glucoside, D-Psicose, D-Raffinose, L-Rhamnose, D-Sorbitol, Sucrose, D-Trehalose, Turanose, Xylitol), 19 amino-acids (D-Alanine, L-Alanine, L-Alanyl-Glycine, L-Asparagine, L-Aspartic Acid, L-Glutamic Acid, Glycyl-L-Aspartic Acid, Glycyl-LGlutamic Acid, L-Histidine, Hydroxy-L-Proline, L-Leucine, L-Ornithine, L-Phenylalanine, L-Proline, DSerine, L-Serine, L-Threonine, D,L-Carnitine, $\gamma$-Aminobutyric Acid), 30 organic acids (Pyruvic Acid Methyl Ester, Succinic Acid Mono-Methyl Ester, Acetic Acid, Cis-Aconitic Acid, Citric Acid, Formic Acid, DGalactonic Acid Lactone, D-Galacturonic Acid, D-Gluconic Acid, D-Glucosaminic Acid, D-Glucuronic Acid, $\alpha$-Hydroxybutyric Acid, $\beta$-Hydroxybutyric Acid, $\gamma$-Hydroxybutyric Acid, p-Hydroxy-phenylacetic Acid, Itaconic Acid, $\alpha$-Ketobutyric, $\alpha$-Ketoglutaric Acid, $\alpha$-Ketovaleric Acid, D,L-Lactic Acid, Malonic Acid, Propionic Acid, Quinic Acid, D-Saccharic Acid, Sebacic Acid, Succinic Acid, Bromosuccinic Acid, Succinamic Acid, L-Pyroglutamic Acid, Urocanic Acid), 3 alcools (m-Inositol, 2,3-Butanediol, Glycerol) et 13 other substrates (tween 40, tween 80, Glucuronamide, L-Alaninamide, Inosine, Uridine, Thymidine, Phenylethyl-amine, Putrescine, 2-Aminoethanol, D,L, $\alpha$-Glycerol Phosphate, $\alpha$-D-Glucose 1-Phosphate, DGlucose-6-Phosphate) .

For insoluble substrates, strains were inoculated on ASW agar plates containing ammonium $(1 \mathrm{~g} / \mathrm{L})$ and one of the following electron donors : Aromatic Hydrocarbon: fluoranthene $(1 \mathrm{mg} / \mathrm{mL})$, phenantrene $(1 \mathrm{mg} / \mathrm{mL})$, dodecylbenzene $(1 \mu \mathrm{L} / \mathrm{mL})$; Fatty acyl hydrocarbon: tetradecane $(1 \mu \mathrm{L} / \mathrm{mL})$, heptadecane $(1 \mu \mathrm{L} / \mathrm{mL})$, wax 
ester ( hexadecyl d'hexadecanoate ; $0.625 \mathrm{mg} / \mathrm{mL}$ ), paraffin (mixture of C19 to C31 alkanes with melting point $\left.52^{\circ} \mathrm{C} ; 2.5 \mathrm{mg} / \mathrm{mL}\right)$; Branched hydrocarbon: pristane $(1 \mu \mathrm{L} / \mathrm{mL})$, glycerolipids: triolein $(5 \mu \mathrm{L} / \mathrm{mL})$, tripalmitin $(7.5 \mathrm{mg} / \mathrm{mL})$. Plates with a mixture of soluble carbon sources or no carbon source were also used as positive and negative control respectively. The plates were incubated aerobically at $20^{\circ} \mathrm{C}$ for two weeks and then overlaid with $10 \mathrm{~mL}$ molten soft agar containing INT $(0.2 \mathrm{~g}$ per liter ASW) and the same carbon source than that used for the growth step. Oxygen respiring colonies in the presence of the selected substrates were identified as those reducing colorless INT into red INT-formazan (Goregues et al. 2004). Results were recorded after 30 minutes incubation.

Mesocosm set up: Sediment was collected at Brittany coast (Celtic Sea, Atlantic Ocean, $48^{\circ} 34^{\prime} 28.2^{\prime}{ }^{\prime} \mathrm{N} 4^{\circ}$ 36'40.2" E) in October 2013. After removing macrofauna, $72 \mathrm{~L}$ of sediments were distributed in 12 mesocosms (boxes 15x20x $30 \mathrm{~cm}$ ). Four conditions were established in triplicate (1) No Nereis ( Hediste. diversicolor) addition and no hydrocarbon amendment (-HC-N), (2) Nereis addition at density of 1000 $\operatorname{organism} / \mathrm{m}^{2}$ and no hydrocarbon amendment $(-\mathrm{HC}+\mathrm{N})(3)$ no Nereis addition and hydrocarbon amendment at $7 \mathrm{~g} / \mathrm{kg}(+\mathrm{HC}-\mathrm{N})$, (4) Nereis addition at density of 1000 organism $/ \mathrm{m}^{2}$ and hydrocarbon amendment at $7 \mathrm{~g} / \mathrm{kg}$ $(+\mathrm{HC}+\mathrm{N})$,. Hydrocarbon addition consist in Ural type petroleum topped at $100^{\circ} \mathrm{C}$ (removal of $\mathrm{HC}<7 \mathrm{C}$ ).

\section{Nucleic acid extraction, quantification by qPCR in mesocoms and characterization of genes of denitrification on strains set}

After 3 months of incubation at $20^{\circ} \mathrm{C}, 5 \mathrm{~g}$ of the 2 first centimeters of sediment in each mesocosm were sampled and nucleic acids were extracted using the MoBio Power soil RNA/DNA extraction kit (MoBio Laboratories, California) according to the manufacturer's protocol. DNAs from cultures of strains were purified as previously reported (Goregues et al. 2005). Purified DNA was stored at $20^{\circ} \mathrm{C}$ until use.

The determinations of 16S rRNA gene copy numbers were performed by real time PCR with SsoAdvanced SYBR Green Supermix using a CFX96 Real Time System (C1000 Thermal Cycler, Bio-Rad Laboratories, CA, USA). The primer sets GML5F-Uni516R (Michotey et al. 2012) and marinob300F (5'GACTGAGACACGGCCCGA-3') - marinob600R (5'-CCGGGGCTTTCACATCTCG-3') were used for quantification of total bacterial 16S rRNA genes and Marinobacter 16S rRNA genes respectively. The real time PCR cycles consisted of a denaturation step of $5 \mathrm{~s}$, a hybridization step of $20 \mathrm{~s}$ at $56^{\circ} \mathrm{C}$ with an elongation step of $40 \mathrm{~s}$. Quantification of bacterial nosZ were performed using nosZ $1211 \mathrm{~F}$ and nosZ 1897R primers (Rosch et al. 2002) and SsoFast EVA Green Supermix (Bio-Rad Laboratories, CA, USA). The real time PCR cycles consist of a denaturation step of $15 \mathrm{~s}$, a hybridization step of $15 \mathrm{~s}$ at $64^{\circ} \mathrm{c}$ with an elongation step of $40 \mathrm{~s}$ at $72^{\circ} \mathrm{C}$. Gene abundance in microcosm DNA samples was determined in relation with a calibration standards corresponding to dilution of plasmids harboring target genes. 
Denitrification activity of strains were determined as previously described (Bonin et al. 1987; 1992; Goregues

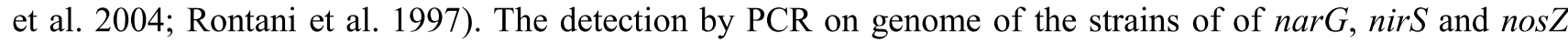
were performed as previously reported(Goregues et al. 2005, Michotey et al. 2000, Rosch et al. 2002) respectively. All amplified DNA fragments were checked by sequencing. The nucleotide sequence data generated in this study have been deposited in the Genbank database under accession numbers KM816585 to KM816618.

Genomes analysis: Sixteen genomes are currently available, M. adhaerens DSM 23420 (CP001978), M. algicola DG893(GCA_000170835.1), $M$ hydrocarbonoclasticus strain VT8 (GCA_000015365.1), M. hydrocarbonoclasticus strain 17 ATCC 49840 (FO203363 ), M excellens (PRJNA195885 ), M. daepoensis DSM 16072 (GCA_000421165.1), M. lipolyticus strain BF04 (GCA_000372805.1), M. lipoliticus strain SM19 (ASAD01000001- ASAD01000006), M. maganoxydans (AGTR00000000), M. nanhaiticus (APLQ01000000) M. santoriniensis (APAT01000000), M. strain AK21 (ANIE01000001- ANIE01000006), M. strain BSs20148 (CP003735 ), M. strain ELB17 (GCA_000169375.1), M. strain MCTG268 (JQMK00000000), M. strain HL-58 (GCA_000686085.1). The metabolic properties harbored by the strain according to their genomes analyses was assessed with IMG-ER (DOE-JGI) platform (https://img.jgi.doe.gov)

Statistical analysis: An ANOVA analysis was used to determine the influence of hydrocarbon amendment and presence of Nereis on bacterial numeration in microcosms. The significance level for all tests was set at $\mathrm{p}<0.05$. All tests were performed with XLSTAT ${ }^{\circledR}$ (XLSTAT software ${ }^{\circledR} 2008$, Addinsoft, Paris).

\section{Results}

In this study we propose new qPCR primers for the detection of Marinobacter ribosomal 16S rDNA (Table 2). Primer set Marinob300f-Marinob600R matches with 64.5\% of ribosomal sequences affiliated to Marinobacter genus in RDP database and $90 \%$ of ribosomal sequence of Marinobacter type strains. Previous qPCR primers (Mab451f-Mab573r) and CARD-FISH probe presented a narrower spectrum of detection since they matched with 6.4 and $26.6 \%$ of Marinobacter ribosomal sequences in RDP, respectively. These percentages dropped to 3 and $20 \%$ for type strains. (Tab.2). Both qPCR primer sets present lower percentage of match toward nontarget sequences $(1.2 \%$ and $2.8 \%)$ in comparison of CARD-FISH probes $(20 \%)$. Optimization of hybridization temperature of the $\mathrm{qPCR}$ was determined $\left(\mathrm{T}=56^{\circ} \mathrm{C}\right)$ in relation with positive (M. hydrocarbonoclasticus) and negative (E. coli) Gammaproteobacteria controls. The resulting conditions lead to a qPCR efficiency of $97.1 \%$ $\left(\mathrm{R}^{2}=0.994\right)$.

Marinobacter dynamic was monitored upon hydrocarbon pollution in sediment mesocosms. Marinobacter and bacterial 16S rRNA gene abundances were measured by qPCR in all mesocosms after 3 months incubations 
(Fig. 1). The highest number of bacterial ribosomal genes (about $10^{11} / \mathrm{g}$ sediment) was observed for the condition without macrofauna and hydrocarbon. For the other conditions, no significant difference in numeration of bacterial 16S rRNA genes was recorded in the mesocosms (about $10^{10} / \mathrm{g}$ sediment) (Fig. 1). The analysis of abundance of Marinobacter ribosomal genes emphasized the predominant impact of hydrocarbon to presence of macrofauna. Indeed, all mesocosms containing hydrocarbon presented significant higher numbers of Marinobacter $(+\mathrm{HC}+\mathrm{N},+\mathrm{HC}-\mathrm{N}>-\mathrm{HC}+\mathrm{N},-\mathrm{HC}-\mathrm{N} ; \mathrm{p}<0.05)$. Their abundance reached 0.3$0.09 \%$ of the bacterial population in presence of $\mathrm{HC}$ in comparison of $0.02-0.004 \%$ in its absence. Whatever the presence of hydrocarbon, the mesocosms without macrofauna harbored lower percentage of Marinobacter than those in which Nereis has been introduced $(0.3$ vs 0.09 and 0.022 vs 0.004 for condition with and without hydrocarbons).

The denitrifying community was quantified using nos $Z$ gene with primers previously used for competitive PCR (Rontani et al. 2010, Fernandes et al. 2012). In qPCR the efficiency of the reaction reached 91.7\%. In mesocosms, the number of bacterial nos $Z$ varied form $6.6610^{6}$ to $3.2410^{7} / \mathrm{g}$ sediment (Fig.1). The ratio nosZ/16S rRNA bacterial genes ranged from $0.1410^{-3}$ to $0.0710^{-3}$ in mesocosms without hydrocarbon amendment to $1.4710^{-3}$ to $0.5710^{-3}$ in its presence. Within a condition ( + or - hydrocarbon) this ratio was higher in presence of macrofauna. In contrast, the ratio denitrifier/Marinobacter (nosZ/Marinobacter 16S rRNA gene)n seemed relatively stable and range between 0.48 and 1.72 (Fig. 1).

The electron donor pattern was determined on a set of 34 isolates which according to phylogenetic tree belong to 7 validated species and 3 potential novel ones referred as phylotype \# 2, \#8, \#9 (S1). Hereafter, validated species and potential novel ones were referred as taxa. Of the 34 tested strains, only 8 were able to use a few carbohydrates as electron donors (S2). All the strains were only able to use less than 4 different carbohydrates, excepted strain T33 (phylotype \#8) oxidizing 16 of them. Glucose was the most commonly utilized (6 isolates) but only occasionally within a taxon (1/11 for $M$ hydrocarbonoclasticus, $2 / 8$ for $M$. vinifirmus; $1 / 2$ for $M$ maritimus, 2/4 for phylotype \#8). The same trend was observed for dextrin since only 4 strains were able to use it (S2). Likewise, amino acid utilization range of Marinobacter strains of this study was restricted to few them; however in contrast to carbohydrates, most of the strains of a taxon shared the same trend toward a given Amino acid. L-proline was the most frequently used by the isolates (8/10 taxa) followed by L-glutamic acid (5/10 taxa) and then L-leucine, (4/10 taxa) (Fig.2). L alanine and D-alanine were oxidized by only few strains within 3 and 4 taxa respectively (S2). Eight out of 30 organic acids tested could be used as electron donors by a least one Marinobacter strain. The most widely used acid was $\beta$-hydroxybutyric acid that was electron donor for 8/10 taxa followed by pyruvic acid methyl ester or D,L lactic acid that were oxidized by 4/10 taxa (Fig.2). The utilization of these 3 organic acids was shared by most of the strains in a taxon (Fig.2 
and S2). In contrast, propionic acid, acetic acid, citric acid, succinic acid and bromo-succinic acid were oxidized at a lesser extent and only occasionally within a taxon.

Among the investigated panel of electron donors, the most used were lipid compounds. All tested molecules were used by several taxa of Marinobacter and all taxa, excepted M. xestospongia strain BP42, could utilized more than half of them. M. hydrocarbonoclasticus and $M$. vinifirmus, represented by 11 and 8 isolates respectively, were used to analyze the representativeness of trait within a taxon. Tween 40 (Polyoxyethylene (20) sorbitan monopalmitate) and Tween 80 (Polyoxyethylene (20) sorbitan monooleate) that are emulsifiers, or triolein that is a glycerolipid were oxidized by all taxa. This feature is also observed for heptadecane, a C17- alkane belonging to fatty acyls. These latter patterns were shared by more than $75 \%$ of the isolates of a taxon in most all cases. The two other alkanes tested, tetradecane, a linear -C14 and pristane, a branched C19 molecule, were oxidized by $9 / 10$ and $6 / 10$ taxa, respectively. Pristane utilization is sparse since only $9 \%$ of isolates of M. hydrocarbonoclasticus ( $9 \%$ ) and $25 \%$ of M. vinifirmus (25\%) were positive, suggesting that it cannot be considered as specific trait of a species. The other substrate molecules were characterized by their low lability due to the presence of one or more aromatic cycles or due to higher melting point. The 3 aromatic molecules, dodecylbenzene, phenanthrene or fluorenthene were oxidized by $6 / 10,5 / 10$ and $6 / 10$ taxa respectively. As for pristane, the utilization pattern of aromatic hydrocarbon was not identical for most of the strain within a taxon. For example, only $18 \%$ and $64 \%$ of $M$. hydrocarbonoclasticus and $12 \%$ and $25 \%$ of $M$. vinifirmus could use fluorenthene or dodecylbenzene respectively. This trend was also observed for very insoluble substrates pertaining to fatty acyls or glycerolipids such as tripalmitate paraffin and wax. Between 5 and 7 taxa were positive for their utilization, with positive strains varying between 12 to $55 \%$ for $M$. hydrocarbonoclasticus and $M$. vinifirmus.

The available genomes corresponded to 10 validated species $(M$. adhaerens, $M$. algicola, $M$ hydrocarbonoclasticus, M excellens, M. daepoensis, M. lipolyticus, M. maganoxydans, M. nanhaiticus, M. santoriniensis, M. psychrophilus ) and a potential novel one (M. sp AK21) (S1). From the analysis of available genomes, similar trends could be emitted on nature of electron donor of Marinobacter. The genomic analysis was focused on proteins mediating the entry of substrates into the cell (translocation protein, transporter, permease, symport) or the first enzyme of a pathway for lipids (Tab. 3). To import many carbohydrates (glucose, mannose, fructose...), Bacteria have developed an unique mechanism the phosphoenolpyruvate:sugar phosphotransferase system (PTS). This system synchronizes the transport of the sugar through the cellular membrane and its phosphorylation. With some variations, the PTS comprises several proteins, some of them are common for all sugars such as EnzI and HPr and others that are specific of a carbohydrate or a group or carbohydrates such as EnzII composed of domain IIA, IIB, IIC. This latter one is located in the membrane and mediates specific sugar translocation. Whereas HPR has been identified in all genomes of Marinobacter, EnZII were scarce (Tab.3). From the panel of genomes, only EnZII A and B genes specific to fructose have been identified in 8 and 5 genomes, respectively; in contrast to EnZII $\mathrm{C}$ for which 
whatever the sugar, no gene could be identified. The absence of the protein responsible for of sugars translocation led to the impossibility to use these compounds as electron donors. For some organic acids such lactate or succinate, putative genes annotated as transporters were found in 5 and 16 genomes, respectively. Proline appeared as an important amino acid since all genomes harbored a sodium/proline symporter. Except the Carboxylate/Amino Acid/Amine transporter that was present on all genomes, the other specific amino acid transporters were either absent or present in only one genome. In contrast, all the strains contained the fatty oxidation complexes $F a d A B$ and a complete $\beta$-oxidation pathway (data not shown). Furthermore, the occurrence of both alkane mono-oxygenase (alkA) and haloalkane dehalogenase genes in genomes was above $87 \%$. The only genome in which alkA has not been detected is M. lipoliticus strain BF04. The genome of this strain did not contain also the gene coding for haloalkane dehalogenase as that of M psychrophylus BSs20148. Long chain alkanes $\left(\mathrm{C}_{32}\right.$ and longer) are oxidized by the product of gene almA that encodes a flavin-binding monooxygenase. Blast search with almaA sequence of M. lipolyticus (FJ263110) from the study of Wang and Shao (2012) and with an E-value cutoff at $10^{-5}$, permit the identification of 13 homologous genes in Marinobacter set of genome. The two strains of $M$. hydrocarbonoclasticus, all 3 strains of $M$ algicola, and strains of $M$ adhaerens, M. manganoxydans, M. daepoensis, M. santoriniensis, M. nanhaiticus, M. excellens, M.lipolyticus SP19 and $M$ strain AK21 were positive.

During denitrification, nitrate is reduced into $\mathrm{N}_{2}$ through several steps. Nitrate can be reduced to nitrite by NarG or NapA, nitrite to nitric oxide by NirS or nirK, nitric oxide to nitrous oxide by NorB, and nitrous oxide to $\mathrm{N}_{2}$ by NosZ. Three genes out of four were tested. Analyses of denitrifying genes revealed the preferential presence of $\operatorname{narG}$, nirS among our denitrifying Marinobacters set (Table 4). Most of the nitrate reducers among our set of strains were able to perform total denitrification and harbored also nosZ. This tendency was also found by genomic approach (Table 3). Denitrification genes the most frequently recovered were $n a r G$ and $n o s Z$ and $75 \%$ of the genomes possessed at least one gene of denitrification.

\section{Discussion}

Hydrocarbons occur as biosynthetic products of living organisms in the biosphere (Ladygina et al. 2006) or as abiotic transformation products of biogenic organic matter in the geosphere (Seewald 2003). They are the main constituents of petroleum and thus are extremely abundant in geological systems. They can be transferred from geosphere to biosphere by different manners such as hydrothermal vent, mud volcano (Whiticar and Suess, 1990; Timmis 2010) or drilling problems. In consequence their presence is probably ubiquitous but in various proportions. Marine ecosystems are frequently exposed to oil pollution. After a spill, the n-alkanes, short chains tend to evaporate or dissolve in seawater. In contrast to short and medium-chain alkanes that are quickly degraded after the spill, the long-chain molecules with more than 18 carbon atoms, do not dissolve nor degrade efficiently and stay for longer periods of time in the environment. Hydrocarbons of a 
spill or from biogenic origin enter with other compounds in the composition of marine organic matter resulting in a complex mixture of molecules having various compositions, physical structures and reactivity. This complexity is probably a major factor for maintaining a high degree of diversity among prokaryotes in oceans. Heterotrophic bacteria recycle dissolved and particulate organic matter and contribute to the productivity of the ecosystem. Isolation campaigns have demonstrated the presence of the heterotrophic Gammaproteobacteria Marinobacter in many marine environments exhibiting disparate characteristics. This finding would suggest that they are capable of oxidizing a wide range of carbon substrates. This physiological studies of 34 isolates and analyses of 16 genomes from diverse marine habitats such as sediment, water column or phycosphere and partitioning into 15 species and 4 potential novel ones within Marinobacter genus give rise to a different view. Except for some strains, very few molecules classified as labile organic matter are used. The spectra of carbohydrates utilization as electron donors determined by physiological as well as genomic approaches are extremely reduced. Comparison of physiological and genomic approaches focusing on transporters was evaluated by comparison of patterns obtained from Marinobacter hydrocarbonoclasticus strain17. From its genome fully annotated (Grimaud et al. 2012), no EnzIIC of sugar could be detected in congruence with results of physiological study. The inability to use carbohydrates or to degrade the polysaccharides has been reported previously for some Marinobacter strains (Bowman and McMeekin 2005). However, our results including a wider list of species and with several strains within a species strengthen this observation that appears as a common trait of this genus.

The ability of Marinobacter to use external amino acids as electron donors was reported. The list of the preferential ones included L-alanine, D glutamate and L phenylalanine (Handley and Lloyd 2013). From our data, the most frequently used by our set of strains is proline and all analyzed genomes contained a specific transporter for this amino acid. This feature was described previously for M. gudaonensis (Gu et al. 2007), and M. koreensi (Kim et al. 2006). With the present study, this characteristic is enlarged to at least 16 species and 4 potential novel ones. Furthermore this amino acid appeared to have an important physiological role due to the very high frequency of its utilization. Proline, is uncommon in proteins but has the characteristic to be compatible solute, that is to say, a molecule involved in resistance to the osmotic pressure, thermal stress for many heterotrophs (Welsh 2000). This ability could allow Marinobacter strains to resist to a wide range of physical parameters.

The main feature which emerges from the analyses of the substrates pattern is the capacity of many strains of Marinobacter to oxidize a very large spectrum of lipid molecules of various type and molecular weight (including Tween). This physiological aspect is not frequently explored in species characterization (Handley and Lloyd 2013). Degradation capacity towards tween is often reported in the literature due to its presence in Biolog panel. For example M. koreensis (Kim et al. 2006), M. lipolyticus strain SM19, M. litoralis (Martin et al. 2003) and M. bryozoorum or M. sediminum (Romanenko et al. 2005) were found positive. For other lipid molecules, except few studies, the degradation pattern toward these compounds remains often untested. $M$. 
hydrocarbonoclasticus is may be one of the best characterized. It can utilize $n$-alkanes ranging from $\mathrm{C}_{6}-\mathrm{C}_{30}$ (Doumenq et al. 2001; Duran 2010; Grimaud 2010 ). This trait seemed largely shared since genomic approach has highlighted the presence of alkane mono-oxygenase, an enzyme responsible for the first step oxidation of fatty acyl hydrocarbon in 15 out of 16 genomes. According to literature, 9 Marinobacter species were identified as hydrocarbon degraders (Handley and Lloyd 2013); our results have identified 9 additional species. This feature was observed for strains isolated from environment enriched with petroleum such as oil producing well in the case of $M$. hydrocarbonoclasticus VT8 but was also observed for strains retrieved from potential petroleum-free samples such as dinoflagelates cultures for $M$ algicola (Green et al. 2006), or microbial mat for the two other genomes affiliated to M algicola (HL-58 and MCTG268), marine particles for M. adhaerens (Gärdes et al 2010) or Artic ocean sediment for M. psychrophilus BSs20148 (Song et al. 2013) for examples. Usually when hydrocarbon utilization is included in physiological characterization, only short chain hydrocarbon are tested. For screening the capacity to degrade long -chain alkanes with more than 18 carbon atoms, the use of almA gene has been recently suggested by Wang and Shao (Wang and Shao 2012). Strains belonging to $M$ koreensis, $M$ alkaliphilus, M. lipolyticus,M. flavimaris and $M$ hydrocarbonoclasticus were found positive by these authors (Wang and Shao 2012). This gene was recovered by specific BlastP on most genomes of our set and this trend was extended to species M. adhaerens, M. manganoxydans, M. algicola, M. daepoensis, M. santoriniensis, M. nanhaiticus, and M. excellens. In this study, the panel of electron donors include short and long chain hydrocarbons but also non-hydrocarbon lipids (glycerolipids). Most of the strains appeared positive. The results of this study highlighted also the need to screen several strains of a same species to find common physiological traits within a species. From previous studies (Timmis 2010 for a review), some Marinobacter type strains were described as short chain alkane degraders, this trend could now be expanded through a larger number of species including several strains within a species and to large spectrum of lipid molecules. These compounds appeared as preferred electron donors for Marinobacter species included in this set.

This capacity could account for the 10 fold increase of Marinobacters abundance in mesocosm contaminated with petroleum of this study. This value is higher than the 2 fold increase observed in anaerobic mesocosm with a CARD-FISH probe exploring only $26 \%$ of Marinobacter sequence (Genovese et al. 2014) but are in agreement with augmentation of Marinobacter ribosomal sequences found by pyrosequencing before and after oil pollution in mangrove (dos Santos et al. 2011). In our study, Marinobacter reached about $0.3 \%$ of the bacterial community in mesocosms containing hydrocarbon which is lower than the value found with less specific probe in anaerobic mesocosm by Genovese et al. (2014). However comparison between different studies should be taken with caution since other factors could be involved such as sensitivity to the load of petroleum or the selection of some species not detected by qPCR or CAR-FISH or a kinetic effect. The highest abundance of Marinobacter was observed in presence of petroleum and burrowing macrofauna. The presence and activity of burrowing macrofauna such as $H$. diversicolor, in sediment can significantly affect the 
repartition of electron acceptors and nutrient availability (Banta and Andersen 2003). In marine sediment, oxygen rapidly decreases with depth but several alternative electron acceptors are available. In absence of oxygen, nitrate is the most favorable electron acceptor since its reduction to $\mathrm{N}_{2}$ yields almost as much energy as aerobic respiration (Canfield et al. 2005). However nitrate concentrations in sediments are low probably due to low in situ production or rapid turnover. Bioturbation by macrofauna can enhance oxygen supply to deeper layers, favoring activity of nitrifying prokaryotes than can provide nitrate for nitrate respiring organisms (Laverock et al. 2011) such as denitrifiers. Some strains of Marinobacter have been shown as able to respire inorganic compounds such as arsenic (Handley et al 2013) or more frequently nitrate (i.e; denitrifier (Bonin et al. 1987; Gilewicz et al. 1997; Rontani et al. 2002; Goregues et al. 2004). The use of molecular technics has shown that narG, nirS and nos $Z$ are present in most of the nitrate reducers included in this study. These genes are frequently identified in genomes also. The denitrification property of type strain of M. pelagius, M. maritimus and M.vinifirmus was either incomplete or negative in previous studies. Our results have shown that at least some member of these species can perform this process. The impact of oil on denitrifying community was also addressed in this study. This community was enumerated with nos $Z$ as validated earlier (Rontani et al. 2010; Fernandes et al. 2012; Nogales et al. 2002). This gene was preferred to nirS since it presents the advantage to be the sole one coding for this enzymatic step. The percentage of nosZ-harboring cells increased under hydrocarbon amendment suggesting a probable role in petroleum degradation. Indeed some studies on isolated strains have reported the property of some Marinobacter to degrade hydrocarbon in anaerobiosis (Rontani et al. 2002).

From the results obtained in this study, primers amplifying a broader spectrum of Marinobacter ribosomal gene have confirmed the increasing prevalence of this genus when confronted with petroleum in mesocosms as previously observed with other technics. This phenomenon seems to be due to the pattern of electron donors of this genus, presenting a large range of lipid compounds and narrow ones with other organic molecules. This result has been confirmed by screening of several species and several strains within a species. Marinobacter development in sediment contaminated by petroleum was favored by burrowing macrofauna which facilitate diffusion of oxygen but also the supply nitrate to denitrifiers, some of whom belonging to Marinobacter genus. The high frequency of genes involved in alkane degradation of this genus would favor the utilization of this genus as proxy of petroleum monitoring. For example, their occurrence in surrounding area of hydrothermal vents (Wang et al 2012; Handley et al 2013) could be an indication of the diffusion of hydrocarbon effluents. However, the increase of Marinobacter in presence to oil pollution could be also the result of an opportunistic physiological trait toward lipid substrates.

\section{Acknowledgement}

This work was supported by ANR (DECAPAGE ANR-11-CESA-0006) 
We thank the captain and shipboard crew of R/V Pelagia and scientific crew. Furthermore, we acknowledge the Royal Netherlands Institute for Sea Research (NIOZ) for the support by the NIOZ-Marine Research Facilities (MRF) on-shore and on board.

Figure captions

Fig.1 Abundance of ribosomal 16S rRNA gene from bacteria or Marinobacter, and of nitrous oxide reductase gene (nosZ) in mesocosm in presence of Hydrocarbon or of burrowing macrofauna (H. diversicolor)

Neither Hydrocarbon amendment nor $H$. diversicolor addition (-HC-N), no Hydrocarbon amendment and $H$. diversicolor addition $(-\mathrm{HC}+\mathrm{N})$, hydrocarbon amendment and no $H$. diversicolor addition $(+\mathrm{HC}-\mathrm{N})$, hydrocarbon amendment and $H$. diversicolor addition $(+\mathrm{HC}+\mathrm{N})$; These values mean the average number of genes detected in triplicated mesocosms. Several subsamples were collected from each mesocosm.

Fig.2 Main electron donors pattern of 10 taxa of Marinobacter, expressed as percentage of positive strains among a taxon. Substrates tested: 30 carbohydrates, 19 AA, 30 organic acids, 12 lipid molecules and 17 other compounds, only relevant results were indicated

\section{references}

Abed RMM, Zein B, Al-Thukair A, de Beer D (2007) Phylogenetic diversity and activity of aerobic heterotrophic bacteria from a hypersaline oil-polluted microbial mat. Syst Appl Microbiol 30: 319-330

Banta GT, Andersen O (2003) Bioturbation and the fate of sediment pollutants - Experimental case studies of selected infauna species. Vie Milieu 53: 233-248

Baumann P, Baumann L (1981) The marine gram negative eubacteria genus Photobacterium, Beneckea, Alteromonas, Pseudomonas and Alcaligenes. In: S-V K (Ed), The Prokaryotes: a handbook on habitats, isolation and identification of bacteria. Mortimer, P. S, New York, NY, pp. 1302-1330

Bonin P, Gilewicz M, Bertrand JC (1987) Denitrification by a Marine Bacterium Pseudomonas-Nautica Strain-617. Ann Inst Pasteur Mic 138: 371-383

Bonin P, Gilewicz M, Bertrand JC (1992) Effects of Oxygen on Pseudomonas-Nautica Growth on N-Alkane with or without Nitrate. Arch Microbiol 157: 538-545

Bordenave S, Goni-Urriza MS, Caumette P, Duran R (2007) Effects of heavy fuel oil on the bacterial community structure of a pristine microbial mat. Appl Environ Microb 73: 6089-6097

Bowman JP, McCammon SA, Brown MV, Nichols DS, McMeekin TA (1997) Diversity and association of psychrophilic bacteria in Antarctic sea ice. Appl Environ Microb 63: 3068-3078

Bowman JP, McMeekin TA (2005): Marinobacter. In: Brenner DJ, Krieg NR , Staley JT (Editors), Bergey's Manual of Systematic Bacteriology. Springer Science, New York, pp. 459-463 
Brito EM, Guyoneaud R, Goni-Urriza M, Ranchou-Peyruse A, Verbaere A, Crapez MAC, Wasserman JCA, Duran R (2006) Characterization of hydrocarbonoclastic bacterial communities from mangrove sediments in Guanabara Bay, Brazil. Res Microbiol 157: 752-762

Canfield DE, Jorgensen BB, Fossing H, Glud R, Gundersen J, Ramsing NB, Thamdrup B, Hansen JW, Nielsen LP, Hall POJ (1993) Pathways of Organic-Carbon Oxidation in 3 Continental-Margin Sediments. Mar Geol 113: 27-40

Canfield DE, Kristensen E, Thamdrup B (2005) Aquatic geomicrobiology. Adv Mar Biol 48: 1-599

Cui ZS, Lai QL, Dong CM, Shao ZZ (2008) Biodiversity of polycyclic aromatic hydrocarbon-degrading bacteria from deep sea sediments of the Middle Atlantic Ridge. Environ Microbiol 10: 2138-2149

Cui Z, Gao W, Xu G, Zheng L (2013) Genome sequence of the polycyclic aromatic hydrocarbon-degrading bacterium strain Marinobacter nanhaiticus D15-8WT Genome Announc . 1: e00301-13

Deppe U, Richnow HH, Michaelis W, Antranikian G (2005) Degradation of crude oil by an arctic microbial consortium. Extremophiles 9: 461-470

dos Santos HF, Cury JC, do Carmo FL, dos Santos AL, Tiedje J, van Elsas JD, Rosado AS, Peixoto RS (2011) Mangrove Bacterial Diversity and the Impact of Oil Contamination Revealed by Pyrosequencing: Bacterial Proxies for Oil Pollution. Plos One: 6

Doumenq P, Aries E, Asia L, Acquaviva M, Artaud J, Gilewicz M, Mille G, Bertrand JC (2001) Influence of $\mathrm{n}$-alkanes and petroleum on fatty acid composition of a hydrocarbonoclastic bacterium: Marinobacter hydrocarbonoclasticus strain 617. Chemosphere 44: 519-528

Duran R (2010): Marinobacter. In: Timmis KN (Ed), Handbook of hydrocarbon and lipid microbiology. Springer-Verlag, Berlin Heidelberg, pp. 1725-1735

Edwards KJ, Rogers DR, Wirsen CO, McCollom TM (2003) Isolation and characterization of novel psychrophilic, neutrophilic, Fe-oxidizing, chemolithoautotrophic alpha- and, gamma-Proteobacteria from the deep sea. Appl Environ Microb 69: 2906-2913

Fernandes SO, Michotey VD, Guasco S, Bonin PC, Bharathi PAL (2012) Denitrification prevails over anammox in tropical mangrove sediments (Goa, India). Mar Environ Res 74: 9-19

Gärdes A, Kaeppel E, Shehzad A, Seebah S, Teeling H, Yarza P, Glöckner F, Grossart H, Ullrich M (2010) Complete genome sequence of Marinobacter adhaerens type strain (HP15) , a diatom-interacting marine microorganism. SIGS 3:97-107

Gauthier MJ, Lafay B, Christen R, Fernandez L, Acquaviva M, Bonin P, Bertrand JC (1992) MarinobacterHydrocarbonoclasticus Gen-Nov, Sp-Nov, a New, Extremely Halotolerant, Hydrocarbon-Degrading Marine Bacterium. Int J Syst Bacteriol 42: 568-576

Genovese M, Crisafi F, Denaro R, Cappello S, Russo D, Calogero R, Santisi S, Catalfamo M, Modica A, Smedile F, Genovese L, Golyshin PN, Giuliano L, Yakimov MM (2014) Effective bioremediation strategy for rapid in situ cleanup of anoxic marine sediments in mesocosm oil spill simulation. Front Microbiol: 5

Gilewicz M, Nimatuzahroh, Nadalig T, Budzinski H, Doumenq P, Michotey V, Bertrand JC (1997) Isolation and characterization of a marine bacterium capable of utilizing 2-methylphenanthrene. Appl Microbiol Biot 48: 528-533

Goregues C, Michotey V, Bonin P (2004) Isolation of hydrocarbonoclastic denitrifying bacteria from berre microbial mats. Ophelia 58: 263-270

Goregues CM, Michotey VD, Bonin PC (2005) Molecular, biochemical, and physiological approaches for understanding the ecology of denitrification. Microb Ecol 49: 198-208

Gorshkova NM, Ivanova EP, Sergeev AF, Zhukova NV, Alexeeva Y, Wright JP, Nicolau DV, Mikhailov VV, Christen R (2003) Marinobacter excellens sp nov., isolated from sediments of the Sea of Japan. Int J Syst Evol Micr 53: 2073-2078

Gray ND, Sherry A, Grant RJ, Rowan AK, Hubert CRJ, Callbeck CM, Aitken CM, Jones DM, Adams JJ, Larter SR, Head IM (2011) The quantitative significance of Syntrophaceae and syntrophic partnerships in methanogenic degradation of crude oil alkanes. Environ Microbiol 13: 2957-2975

Green DH, Bowman JP, Smith EA, Gutierrez T, Bolch CJS (2006) Marinobacter algicola sp nov., isolated from laboratory cultures of paralytic shellfish toxin-producing dinoflagellates. Int J Syst Evol Micr 56: 523-527 
Grimaud R (2010) Marinobacter. In: Timmis KN (Ed), Handbook of hydrocarbon and lipid microbiology. Springer-Verlag, Berlin Heidelberg, pp. 1289-1296

Grimaud R, Ghiglione JF, Cagnon C, Lauga B, Vaysse, PJ, Rodriguez-Blanco A, Mangenot A, Cruveiller S, Barbe V, Duran R, Wu LF, Talla E, Bonin P, Michotey V (2012) Genome sequence of the marine bacterium Marinobacter hydrocarbonoclasticus SP17 which forms biofilms on hydrophobic organic compounds. J Bacteriol 94:3539-40

Gu J, Cai H, Yu SL, Qu R, Yin B, Guo YF, Zhao JY, Wu XL (2007) Marinobacter gudaonensis sp nov., isolated from an oil-polluted saline soil in a Chinese oilfield. Int J Syst Evol Micr 57: 250-254

Handley KM, Lloyd JR (2013) Biogeochemical implications of the ubiquitous colonization of marine habitats and redox gradients by Marinobacter species. Front Microbiol 4

Handley KM, Upton M, Beatson S, Lloyd JR (2013) genome sequence of thermal arsenic -respiring bacterium Marinobacter santoriniensis NKSG1. Genome Announc 1:e00231-13

Huu NB, Denner EBM, Ha DTC, Wanner G, Stan-Lotter H (1999) Marinobacter aquaeolei sp. nov., a halophilic bacterium isolated from a Vietnamese oil-producing well. Int J Syst Bacteriol 49: 367-375

Karner M, Fuhrman JA (1997) Determination of active marine bacterioplankton: A comparison of universal 16S rRNA probes, autoradiography, and nucleoid staining. Appl Environ Microb 63: 1208-1213

Kim BY, Weon HY, Yoo SH, Kim JS, Kwon SW, Stackebrandt E, Go SJ (2006) Marinobacter koreensis sp nov., isolated from sea sand in Korea. Int J Syst Evol Micr 56: 2653-2656

Ladygina N, Dedyukhina E, Vainshtein M (2006) A review on microbial synthesis of hydrocarbons. Process Biochem 41:1001-1014

Lamendella R, Strutt S, Borglin S, Chakraborty R, Tas N, Mason OU, Hultman J, Prestat E, Hazen TC, Jansson JK (2014) Assessments of the Deepwater Horizon oil spill impact on Gulf coast microbial communities. Front Microbiol 5

Laverock B, Gilbert JA, Tait K, Osborn AM, Widdicombe S (2011) Bioturbation: impact on the marine nitrogen cycle. Biochem Soc T 39: 315-320

Lee OO, Lai PY, Wu HX, Zhou XJ, Miao L, Wang H, Qian PY (2012) Marinobacter xestospongiae sp nov., isolated from the marine sponge Xestospongia testudinaria collected from the Red Sea. Int J Syst Evol Micr 62: 1980-1985

Marquez MC, Ventosa A (2005) Marinobacter hydrocarbonoclasticus Gauthier et al. 1992 and Marinobacter aquaeolei Nguyen et al. 1999 are heterotypic synonyms. Int J Syst Evol Micr 55: 1349-1351

Martin S, Marquez MC, Sanchez-Porro C, Mellado E, Arahal DR, Ventosa A (2003) Marinobacter lipolyticus sp nov., a novel moderate halophile with lipolytic activity. Int J Syst Evol Micr 53: 1383-1387

Michotey V, Mejean V, Bonin P (2000) Comparison of methods for quantification of cytochrome cd(1)denitrifying bacteria in environmental marine samples. Appl Environ Microb 66: 1564-1571

Michotey V, Guasco S, Boeuf D, Morezzi N, Durieux B, Charpy L, Bonin P (2012) Spatio-temporal diversity of free-living and particle-attached prokaryotes in the tropical lagoon of Ahe atoll (Tuamotu Archipelago) and its surrounding oceanic waters. Mar Pollut Bull 65: 525-537

Mikucki JA, Priscu JC (2007) Bacterial diversity associated with blood falls, a subglacial outflow from the Taylor Glacier, Antarctica. Appl Environ Microb 73: 4029-4039

Nogales B, Timmis KN, Nedwell DB, Osborn AM (2002) Detection and diversity of expressed denitrification genes in estuarine sediments after reverse transcription-PCR amplification from mRNA. Appl Environ Microb 68: 5017-5025

Romanenko LA, Schumann P, Rohde M, Zhukova NV, Mkhailov VV, Stackebrandt E (2005) Marinobacter bryozoorum $\mathrm{sp}$ nov and Marinobacter sediminum sp nov., novel bacteria from the marine environment. Int J Syst Evol Micr 55: 143-148

Rontani JF, Gilewicz MJ, Michotey VD, Zheng TL, Bonin PC, Bertrand JC (1997) Aerobic and anaerobic metabolism of 6,10,14-trimethylpentadecan-2-one by a denitrifying bacterium isolated from marine sediments. Appl Environ Microb 63: 636-643

Rontani JF, Mouzdahir A, Michotey V, Bonin P (2002) Aerobic and anaerobic metabolism of squalene by a denitrifying bacterium isolated from marine sediment. Arch Microbiol 178: 279-287

Rontani JF, Nassiry M, Michotey V, Guasco S, Bonin P (2010) Formation of pristane from alpha-tocopherol under simulated anoxic sedimentary conditions: A combination of biotic and abiotic degradative processes. Geochim Cosmochim Ac 74: 252-263 
Rosch C, Mergel A, Bothe H (2002) Biodiversity of denitrifying and dinitrogen-fixing bacteria in an acid forest soil. Appl Environ Microb 68: 3818-3829

Seewald J (2003) Organic-inorganic interactions in petroleum-producing sedimentary basins. Nature 426:327333

Shieh WY, Jean WD, Lin YT, Tseng M (2003) Marinobacter lutaoensis sp nov., a thermotolerant marine bacterium isolated from a coastal hot spring in Lutao, Taiwan. Can J Microbiol 49: 244-252

Song L, Ren L, Li X, Yu D, Wang X, Liu G (2013) Complete genome sequence of Marinobacter sp.BSs20148. genom a Genome Announc 1:e00236-13

Sproer C, Lang E, Hobeck P, Burghardt J, Stackebrandt E, Tindall BJ (1998) Transfer of Pseudomonas nautica to Marinobacter hydrocarbonoclasticus. Int J Syst Bacteriol 48: 1445-1448

Stauffert M, Cravo-Laureau C, duran R (2014) Structure of hydrocarbonoclastic nitrate reducing bacterial communities in bioturbated coastal marine sediment. Fems Microbiol Ecol 89: 580-593

Takai K, Moyer CL, Miyazaki M, Nogi Y, Hirayama H, Nealson KH, Horikoshi K (2005) Marinobacter alkaliphilus sp nov., a novel alkaliphilic bacterium isolated from subseafloor alkaline serpentine mud from Ocean Drilling Program Site 1200 at South Chamorro Seamount, Mariana Forearc. Extremophiles 9: 17-27

Thane Papke R, de la Haba R, Infante-Domínguez C, Pérez D, Sánchez-Porro C, Lapierre P, Ventosa A (2013) Draft genome sequence of the moderately halophilic bacterium Marinobacter lipolyticus strain SM19. Genome Announc 1:e00379-13

Timmis KN (2010), Handbook of hydrocarbon and lipid microbiology. Springer-Verlag, Berlin Heidelberg,

Wang WP, Shao ZZ (2012) Diversity of flavin-binding monooxygenase genes (almA) in marine bacteria capable of degradation long-chain alkanes. Fems Microbiol Ecol 80: 523-533

Wang H, Li H, Shao Z, Liao S, Johnstone L, Rensing C, Wang G (2012) Genome sequence of deep-sea Manganese-oxidizing bacterium Marinobacter manganoxydans MnI7-9. J Bacteriol 194: 899-900.

Welsh DT (2000) Ecological significance of compatible solute accumulation by micro-organisms: from single cells to global climate. Fems Microbiol Rev 24: 263-290

Whiticar MJ, Suess E (1990) Hydrothremal hydrocarbon gases in the sediments of king George Basin, Branfield strait Antartica. Appl. Geochem. 5: 135-147

Yakimov MM, Giuliano L, Crisafi E, Chernikova TN, Timmis KN, Golyshin PN (2002) Microbial community of a saline mud volcano at San Biagio-Belpasso, Mt. Etna (Italy). Environ Microbiol 4: 249-256

Yoon JH, Yeo SH, Kim IG, Oh TK (2004) Marinobacter flavimaris sp nov and Marinobacter daepoensis sp nov., slightly halophilic organisms isolated from sea water of the Yellow Sea in Korea. Int J Syst Evol Micr 54: 1799-1803 
Table 1

List of Marinobacter strains used in this study

\begin{tabular}{|c|c|c|c|c|c|}
\hline Species & Strains & \begin{tabular}{|c|}
$\begin{array}{c}\text { Location } \\
\text { of } \\
\text { isolation }\end{array}$ \\
\end{tabular} & $\begin{array}{l}\text { Type of } \\
\text { sample }\end{array}$ & Reference & \begin{tabular}{|c|} 
Physiological \\
(P), genomic \\
(G) analysis \\
\end{tabular} \\
\hline \multirow{6}{*}{$\begin{array}{l}\text { M. } \\
\text { hydrocarbonoclasticus }\end{array}$} & \begin{tabular}{|l|} 
VT8, DSM \\
$11845^{\mathrm{a}}$
\end{tabular} & Vietnam & $\begin{array}{l}\text { Oil producing } \\
\text { well }\end{array}$ & $\begin{array}{l}\text { (Huu et al. } \\
\text { 1999) }\end{array}$ & $P, G$ \\
\hline & $\mathrm{DN} 1^{\mathrm{a}}$ & \begin{tabular}{|l} 
Gulf of \\
Fos, Med \\
Sea
\end{tabular} & sediment & $\left(\begin{array}{l}\text { (Bonin et al. } \\
1987)\end{array}\right.$ & $\mathrm{P}$ \\
\hline & $\begin{array}{l}17 \text { ATCC } \\
49840\end{array}$ & \begin{tabular}{|l|} 
Gulf of \\
Fos, Med \\
Sea \\
\end{tabular} & sediment & $\begin{array}{l}\text { (Gauthier et } \\
\text { al. 1992) }\end{array}$ & P, G \\
\hline & CAB & \begin{tabular}{|l} 
Gulf of \\
Fos, Med \\
Sea \\
\end{tabular} & sediment & \begin{tabular}{||l} 
(Gilewicz et \\
al. 1997)
\end{tabular} & P \\
\hline & \begin{tabular}{|l} 
BC36, \\
BC38, R153
\end{tabular} & $\begin{array}{l}\text { Berre } \\
\text { lagoon, } \\
\text { Med Sea }\end{array}$ & sediment & \begin{tabular}{|l} 
(Goregues \\
et al. 2004)
\end{tabular} & $\mathrm{P}$ \\
\hline & \begin{tabular}{|l} 
23W2B, \\
CUBW5A, \\
CUBW5B, \\
23tet5B \\
\end{tabular} & North Sea & Water column & This study & P \\
\hline M. vinifirmus & $\begin{array}{l}\text { BC45, } \\
\text { NBC44, } \\
\text { NBC35, } \\
\text { NBC34, } \\
\text { NBC33, } \\
\text { NBC32, } \\
\text { BC43, } \\
\text { BC34 }\end{array}$ & $\begin{array}{l}\text { Berre } \\
\text { lagoon, } \\
\text { Med Sea }\end{array}$ & ||sediment & \begin{tabular}{||l} 
(Goregues \\
et al. 2004)
\end{tabular} & $\mathrm{P}$ \\
\hline M. maritimus & $\begin{array}{l}\text { 2Sq31 } \\
1 \mathrm{sq53}\end{array}$ & \begin{tabular}{|l} 
Gulf of \\
Fos, Med \\
Sea
\end{tabular} & || sediment & $\begin{array}{l}\text { (Rontani et } \\
\text { al. 2002) }\end{array}$ & P \\
\hline $\begin{array}{l}\text { M. flavimari } M \text {. } \\
\text { adhaerens } M . \\
\text { manganoxydans }\end{array}$ & $\begin{array}{l}\text { Cubtrip2B, } \\
\text { Cubtet1B }\end{array}$ & North Sea & Water column & This study & $\mathrm{P}$ \\
\hline M. adhaerens & $\begin{array}{l}H P 15 \text { DSM } \\
23420\end{array}$ & $\begin{array}{l}\text { German } \\
\text { Wadden } \\
\text { Sea }\end{array}$ & \begin{tabular}{|l} 
Diatom \\
interaction
\end{tabular} & \begin{tabular}{|l} 
(Gärdes et \\
al. 2010)
\end{tabular} & G \\
\hline M. manganoxydans & MnI7-9 & $\begin{array}{l}\text { Indian } \\
\text { Ocean }\end{array}$ & \begin{tabular}{|l} 
Deep-sea \\
hydrothermal \\
vent sediment \\
\end{tabular} & \begin{tabular}{|l} 
(Wang et al. \\
2012)
\end{tabular} & G \\
\hline M. pelagius & R171, R42 & Berre & Sediment & (Goregues & $\mathrm{P}$ \\
\hline
\end{tabular}




\begin{tabular}{|c|c|c|c|c|c|}
\hline Species & Strains & \begin{tabular}{|c|}
$\begin{array}{c}\text { Location } \\
\text { of } \\
\text { isolation }\end{array}$ \\
\end{tabular} & $\begin{array}{l}\text { Type of } \\
\text { sample }\end{array}$ & Reference & \begin{tabular}{|l} 
Physiological \\
(P), genomic \\
(G) analysis \\
\end{tabular} \\
\hline & & $\begin{array}{l}\text { lagoon, } \\
\text { Med Sea }\end{array}$ & & et al. 2004) & \\
\hline \multirow{3}{*}{ M. algicola } & DG893 & Culture & Dinoflagellates & \begin{tabular}{|l} 
(Green et al. \\
$2006)$
\end{tabular} & $P, G$ \\
\hline & $H L-58$ & - & Microbial mat & unpublished & $\mathrm{G}$ \\
\hline & MCTG268 & - & Microbila mat & unpublished & $G$ \\
\hline M. xestospongiae & BP42 & $\begin{array}{l}\text { Berre } \\
\text { lagoon, } \\
\text { Med Sea }\end{array}$ & sediment & \begin{tabular}{|l} 
(Goregues \\
et al. 2004)
\end{tabular} & P \\
\hline M. daepoensis & $\begin{array}{l}S W-156^{T} \\
(D S M \\
16072)\end{array}$ & $\begin{array}{l}\text { South } \\
\text { Korea }\end{array}$ & Water column & $\mid \begin{array}{l}\text { (Yoon et al. } \\
\text { 2004) }\end{array}$ & G \\
\hline M. santoriniensis & NKSG1 & $\begin{array}{l}\text { Santorini, } \\
\text { Med Sea }\end{array}$ & $\begin{array}{l}\text { Shallow marine } \\
\text { hydrothermal } \\
\text { sediment; }\end{array}$ & \begin{tabular}{|l} 
(Handley et \\
al. 2013)
\end{tabular} & G \\
\hline \multirow[t]{2}{*}{ M. lipolyticus } & SM19 & Spain & |saline soil & $\begin{array}{l}\text { (Papke et al. } \\
2013)\end{array}$ & G \\
\hline & BF04_CF-4 & - & - & unpublished & $\mathrm{G}$ \\
\hline M. nanhaiticus & D15-8 W & \begin{tabular}{|l} 
South \\
China Sea
\end{tabular} & || Sediment & $\begin{array}{l}\text { (Cui et al. } \\
\text { 2013) }\end{array}$ & G \\
\hline M. excellens & HL-55 & - & - & unpublished & 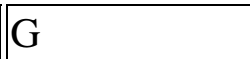 \\
\hline \multirow[t]{2}{*}{ M. psychrophilus } & ELB17 & Antarctica & $\begin{array}{l}\text { Waters of a } \\
\text { permanently } \\
\text { ice-covered } \\
\text { lake }\end{array}$ & unpublished & G \\
\hline & BSs20148 & $\begin{array}{l}\text { Arctic } \\
\text { Ocean }\end{array}$ & |Sediment & $\begin{array}{l}\text { (Song et al. } \\
2013)\end{array}$ & G \\
\hline M. strain AK21 & AK21 & India & Water column & unpublished & $G$ \\
\hline M. sp. phylotype no. 2 & $\begin{array}{l}\text { BP45, } \\
\text { NBP42 }\end{array}$ & $\begin{array}{l}\text { Berre } \\
\text { lagoon, } \\
\text { Med Sea }\end{array}$ & || Sediment & \begin{tabular}{|l} 
(Goregues \\
et al. 2004)
\end{tabular} & P \\
\hline M. sp. phylotype no. 8 & \begin{tabular}{||} 
U32, S64, \\
T33, U31
\end{tabular} & $\begin{array}{l}\text { Berre } \\
\text { lagoon, } \\
\text { Med Sea }\end{array}$ & || Sediment & \begin{tabular}{|l} 
(Goregues \\
et al. 2004)
\end{tabular} & P \\
\hline M. sp. phylotype no. 9 & R53 & $\begin{array}{l}\text { Berre } \\
\text { lagoon } \\
\text { Med Sea }\end{array}$ & || Sediment & $\mid \begin{array}{l}\text { (Goregues } \\
\text { et al. 2004) }\end{array}$ & P \\
\hline
\end{tabular}


Table 2

Comparison of different PCR primers or probes for detection of Marinobacter 16S rDNA using probe-match (RDP probe match tool)

\begin{tabular}{|c|c|c|c|}
\hline \multirow{2}{*}{ Primer set } & $\begin{array}{l}\text { Marinob300F- } \\
\text { Marinob600R } \\
\end{array}$ & Mab451f-Mab573r & CARD-FISH probe \\
\hline & $\begin{array}{c}\text { Number of hits (\% } \\
\text { recovery) }\end{array}$ & $\begin{array}{c}\text { Number of hits (\% } \\
\text { recovery) }\end{array}$ & $\begin{array}{c}\text { Number of hits (\% } \\
\text { recovery) }\end{array}$ \\
\hline Reference & This study & (Gray et al. 2011) & $\begin{array}{l}\text { (Karner and Fuhrman } \\
\text { 1997) }\end{array}$ \\
\hline Bacteria & $2414 / 2879170$ & $242 / 2879170$ & $885 / 2879170$ \\
\hline Marinobacter genus & $2374 / 3639(64.5 \%)$ & $235 / 3639(6.4 \%)$ & $714 / 3639(20.6 \%)$ \\
\hline $\begin{array}{l}\begin{array}{l}\text { Marinobacter type } \\
\text { strains }\end{array} \\
\end{array}$ & $27 / 30(90 \%)$ & $1 / 30(3 \%)$ & || $8 / 30$ (26.6 \%) \\
\hline Non-target matches & $30 / 2414(1.2 \%)$ & $7 / 242(2.8 \%)$ & $171 / 885(20 \%)$ \\
\hline
\end{tabular}

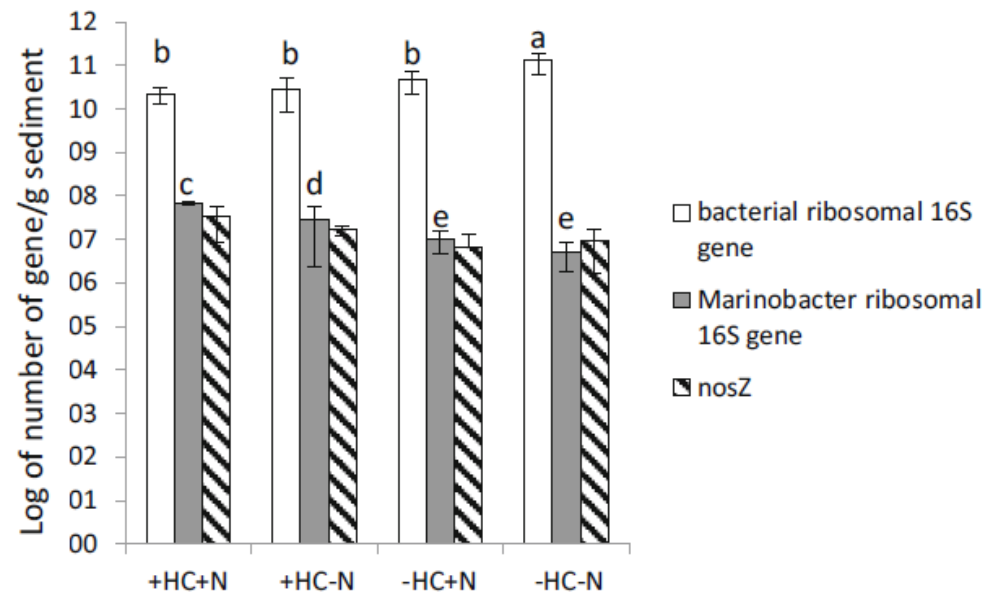

Fig. 1 Abundance of ribosomal 16S rRNA gene from bacteria or Marinobacter and of nitrous oxide reductase gene (nosZ) in mesocosm in the presence of hydrocarbon or of burrowing macrofauna ( $H$. diversicolor). Neither hydrocarbon amendment nor $H$. diversicolor addition $(-\mathrm{HC}-\mathrm{N})$, no Hydrocarbon amendment and $H$. diversicolor

addition $(-\mathrm{HC}+\mathrm{N})$, hydrocarbon amendment and no $H$. diversicolor addition $(+\mathrm{HC}-\mathrm{N})$, hydrocarbon amendment and $H$. diversicolor addition $(+\mathrm{HC}+\mathrm{N})$. These values mean the average number of genes detected in triplicated mesocosms. Several subsamples were collected from each mesocosm 


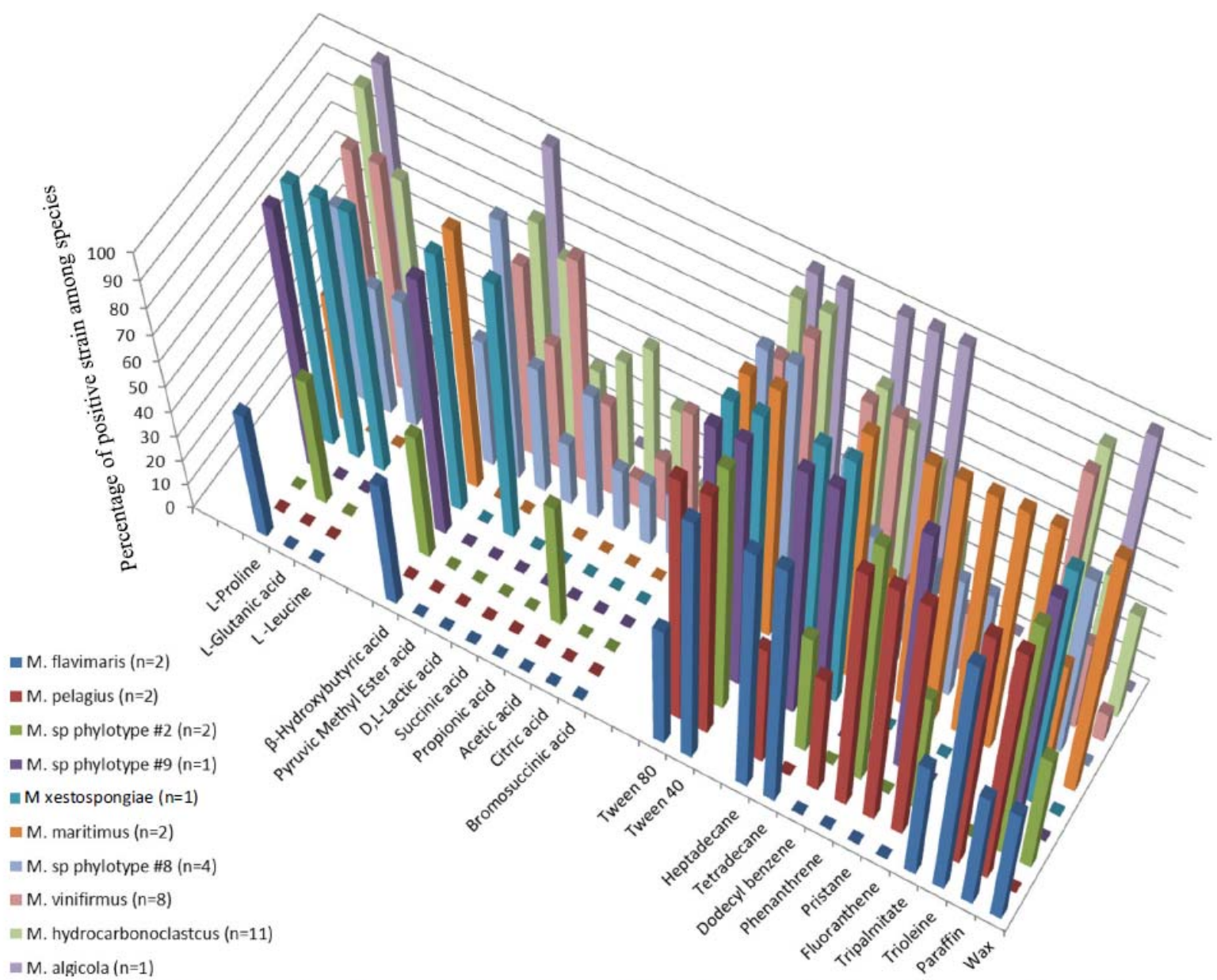

Fig. 2 Main electron donors pattern of 10 taxa of Marinobacter, expressed as percentage of positive strains among a taxon. Substrates

tested: 30 carbohydrates, 19 AA, 30 organic acids, 12 lipid molecules, and 17 other compounds; only relevant results were indicated 